\title{
Towards Integration of Security and Safety Measures for Critical Infrastructures Based on Bayesian Networks and Graph Theory: A Systematic Literature Review
}

\author{
Sandeep Pirbhulal ${ }^{1,2, *}$, Vasileios Gkioulos ${ }^{1}$ and Sokratis Katsikas ${ }^{1}$ (D) \\ 1 Department of Information Security and Communication Technology, Norwegian University of Science and \\ Technology, 2815 Gjøvik, Norway; vasileios.gkioulos@ntnu.no (V.G.); sokratis.katsikas@ntnu.no (S.K.) \\ 2 Norwegian Computing Center, P.O. Box 114, Blindern, 0314 Oslo, Norway \\ * Correspondence: sandeep@nr.no; Tel.: +47-41-393-687
}

\section{check for} updates

Citation: Pirbhulal, S.; Gkioulos, V.; Katsikas, S. Towards Integration of Security and Safety Measures for Critical Infrastructures Based on Bayesian Networks and Graph Theory: A Systematic Literature Review. Signals 2021, 2, 771-802. https://doi.org/10.3390/ signals2040045

Academic Editors: Vessela Krasteva and Toshihisa Tanaka

Received: 15 June 2021

Accepted: 28 October 2021

Published: 2 November 2021

Publisher's Note: MDPI stays neutral with regard to jurisdictional claims in published maps and institutional affiliations.

Copyright: (c) 2021 by the authors. Licensee MDPI, Basel, Switzerland. This article is an open access article distributed under the terms and conditions of the Creative Commons Attribution (CC BY) license (https:// creativecommons.org/licenses/by/ $4.0 /)$.

\begin{abstract}
In recent times, security and safety are, at least, conducted in safety-sensitive or critical sectors. Nevertheless, both processes do not commonly analyze the impact of security risks on safety. Several scholars are focused on integrating safety and security risk assessments, using different methodologies and tools in critical infrastructures (CIs). Bayesian networks (BN) and graph theory (GT) have received much attention from academia and industries to incorporate security and safety features for different CI applications. Hence, this study aims to conduct a systematic literature review (SLR) for co-engineering safety and security using BN or GT. In this SLR, the preferred reporting items for systematic reviews and meta-analyses recommendations (PRISMA) are followed. Initially, 2295 records (acquired between 2011 and 2020) were identified for screening purposes. Later on, 240 articles were processed to check eligibility criteria. Overall, this study includes 64 papers, after examining the pre-defined criteria and guidelines. Further, the included studies were compared, regarding the number of required nodes for system development, applied data sources, research outcomes, threat actors, performance verification mechanisms, implementation scenarios, applicability and functionality, application sectors, advantages, and disadvantages for combining safety, and security measures, based on GT and BN. The findings of this SLR suggest that $\mathrm{BN}$ and GT are used widely for risk and failure management in several domains. The highly focused sectors include studies of the maritime industry (14\%), vehicle transportation (13\%), railway (13\%), nuclear $(6 \%)$, chemical industry $(6 \%)$, gas and pipelines $(5 \%)$, smart grid $(5 \%)$, network security $(5 \%)$, air transportation (3\%), public sector (3\%), and cyber-physical systems (3\%). It is also observed that $80 \%$ of the included studies use BN models to incorporate safety and security concerns, whereas $15 \%$ and 5\% for GT approaches and joint GT and BN methodologies, respectively. Additionally, 31\% of identified studies verified that the developed approaches used real-time implementation, whereas simulation or preliminary analysis were presented for the remaining methods. Finally, the main research limitations, concluding remarks and future research directions, are presented
\end{abstract}

Keywords: graph theory; Bayesian networks; safety; security; critical infrastructures; literature review

\section{Introduction}

In recent times, the growth of the internet of things (IoT) and information communication technologies (ICT) have revolutionized the modern era and critical infrastructures (CIs), including smart manufacturing, healthcare, energy sector, education, and maritime transportation, among others [1,2]. On the one hand, modern communication and electronic technologies have provided many facilities to individuals and nations in different CIs. On the other hand, safeguarding security and safety are essential requirements to offer authenticated operations against possible cyber threats and crises within the respective CIs [3]. Generally, the security mechanisms focus on recognizing and managing risks interrelated with accessibility, privacy, and integrity of devices in CIs. However, safety 
approaches are inclined to predict, classify, and resolve the vulnerabilities linked with the safety of humans, systems, and infrastructures. Therefore, integrating both aspects can help identify potential vulnerabilities and threats and the evaluate probable risks associated with the security and safety of CIs.

The incorporation of security and safety aspects has received massive attention worldwide $[4,5]$. Recent research shows that safety, especially cybersecurity, share interdependencies in many products, especially cyber-physical systems (CPS) [6]. Besides safety regulations interfering in possible security solutions, a fundamental problem is the rising number of cybersecurity threats that negatively impact the affected functional safety and reliability of systems [7]. In safety-sensitive environments, such as the in railway, aircraft, or automotive industries, the consideration of security is widespread [8]. Decision-makers must determine whether the identified issue is due to an attack or technical failure. A precise diagnosis is crucial for an effective response to identified problems. For example, fixing or exchanging the module responsible for the observed issue could be a reasonable response tactic for a technical failure. Simultaneously, blocking an attack vector, utilizing an identified adversary-caused problem, might be an efficient response monitoring strategy.

If the decision-makers can calculate that the apparent problem is an attack, the efficient response policies to resist each attack vector would be dissimilar. For example, the operative response approach for an information manipulation threat on the device could acquire data integrity checks. In contrast, the active response approach against the physical tampering of the device would augment access control. Remarkably, the decision supporting the regulation of the utmost probable root cause for evident problems is not available. In these conditions, Bayesian networks (BNs) could be helpful to solve this problem, mainly cybersecurity and safety applications [4-7]. In BNs, both qualitative and quantitative components are included, such as the directed acyclic graph (DAG) and conditional probability table (CPT), for each node in the DAG, respectively [8]. Furthermore, the graph theory (GT) and neutral network are also incorporated with the safety aspects of network security [9].

Some systematic literature reviews (SLRs) or literature reviews related to safety and security, based on BNs or GT, are available in the literature. Sharma et al. presented a systematic review of safety and security measures for machine learning-enabled agricultural applications. The focus of this study was BN approaches; however, GT was not addressed [10]. Gupta et al. performed a systematic review on blockchain-oriented security outbreak resilience systems for self-governing automobiles. The main limitations are that vehicle applications and their safety aspects are not considered [11]. Chockalingam et al. conducted SLR on 17 BN-based models for integrating cybersecurity and safety measures in different applications [12]. The main drawback of this SLR includes that it merely emphasized BN models; however, GT was not addressed. Lallie et al. reviewed the threat graphs and visual tree syntax-based GT mechanisms, which describe the cyber-attacks central theory, before elaborating on how vital components of a cyber-attack are characterized in attack graphs and outbreak trees. However, safety concerns are not addressed [13]. The main problem with the studies mentioned above is that the SLR or review, based on either GT or $\mathrm{BN}$, ensures safety and security. Since GT and BN are practical approaches to analyzing safety and security risks, there is still a lack of SLR based on both these approaches.

This SLR aims to present current inclinations and advancements, as well as the limitations of incorporating safety and security using GT and BN. The chief contributions of this study are the following:

(a) To identify records, using search queries from numerous databases, including Scopus, $\mathrm{ACM}$, and the Web of Sciences, focusing on united safety and security using GT and $\mathrm{BN}$ models.

(b) To perform a comprehensive comparative interpretation of classified approaches, regarding threat actors, performance verification mechanisms, the number of applied nodes for system development, and implementation scenarios, among others, for combining safety and security aspects using GT or BN methodologies. 
(c) To illustrate the research consequences of this SLR, based on pre-defined research questions (RQs).

(d) To elaborate pros and cons, limitations, and future research directions of BN and GT approaches for integrating safety and security.

The organization of this paper is stated as follows: the background, to analyze security and safety risks for CIs using BN and GT approaches, is represented in Section 2. In Section 3, the research design, including research questions (RQs), search query, and pre-defined criteria of records, are demonstrated. In Section 4, the identified studies were compared in different aspects, such as application sectors, implementation criteria, applicability, etc. The discussion of RQs, based on included studies, as well as the limitations, are presented in Section 5. Finally, in Section 6, the concluding remarks and future research directions are represented.

\section{Background}

Incorporating safety and security has received great attention for different applications; a few unified approaches have been designed to evaluate both measures. Though security analysis is implemented in the overall design procedure, it is generally not combined into the safety analysis development $[5,14]$. Recently, the introduced approaches comprehended the significance of integrated safety and security analysis and intended to incorporate both into a joint methodological process. Two applicable techniques, which describe the integration of security into safety analysis, recommend a merging of fault tree analysis (FTA) with attack tree analysis (ATA) [14] or boolean driven Markov processes (BDMP) [15]. Other introduced approaches either combine safety and security methods, e.g., ATA and bowtie analysis [16], or integrate both fields. However, there are not any practical mechanisms to deal with safety and security integration in real-time applications. Moreover, $\mathrm{BN}$ - and GT-enabled approaches have received much attention worldwide, as a solution offering safety and security in several domains.

\subsection{Bayesian Networks}

The BN (referred to as belief networks) represents a hypothesis of rationalizing from uncertain evidence to uncertain conclusions, since it can perform the factorization of the collective distribution of variables, based on the conditional dependencies. BN is helpful in addressing uncertainty and incompleteness problems; thus, it is extensively applied in several domains. BN graphically depicts the logical associations between variables and recognizes the connections between these variables by conditional probabilities. By interpretation, a BN represents a directed acyclic graph (DAG), which encodes a conditional probability distribution. Nodes and arcs are vital components of BN, the nodes symbolize arbitrary variables and the arcs signify random relations between variables. There is a probability function for each state of the node, and conditional probabilities are used to exhibit the associations between variables.

BNs are probabilistic graphical models; these visual structures characterize the information about an uncertain system [17]. BNs are generally utilized for examining the hazards and vulnerabilities of networks, which are acyclic graphs that provide a quantitative and qualitative assessment of risks. Judea Pearl initially proposed the BN-based approach in 1985 and was usually utilized to distribute random information in AI. Owing to the unique functionality of $\mathrm{BN}$ for constructing the structures and algorithms, it is successfully used in e-commerce, transportation, data mining, energy control, etc. It is a DAG-based probability rationalization and appropriate for uncertainty representation of queries. BN must be a DAG and CPT (conditional probability table). 
BN has been demonstrated to be a powerful tool for solving several problems with uncertain knowledge illustration and reasoning [18-20]. The BN formula is represented in Equation (1):

$$
P\left(X_{j} \mid Y\right)=\frac{P\left(\frac{Y}{X_{j}}\right) P\left(X_{j}\right)}{\sum_{j=1}^{m} P\left(\frac{Y}{X_{j}}\right) P\left(X_{j}\right)}
$$

where $\mathrm{P}(. \mid$ I .) stands for the conditional probability distribution. Suppose the sample space $\mathrm{N}$ of experiment $\mathrm{L}$, " $Y$ " is the random event of $L . X_{1}, X_{2}, \ldots, X_{n}$ is the incompatible set of possibilities in experiment $L$, and " $X_{j}$ " represents the entire group event from $(j=1,2, \ldots, m)$.

Figure 1 represents the three-variable examples of BN structure. A BN comprehends two types of nodes, i.e., the parent and child nodes. The parent node (cause) is at the start of any directed edge; the child node (fruit) is at the end. The directed edge specifies that the two nodes are interrelated. In Figure $1, X, Y$ are the two-parent nodes of $Z$. $Z$ is the child nodes of $X$ and $Y$. Prior probability: $P(X)$ characterizes the probability of event $X ; P(Y)$ is the probability of event $Y ; P(Z \mid X, Y)$ is the probability that the event $Z$ occurs before the condition that occurs at $\mathrm{X}$ and $\mathrm{Y}$. The posterior probability, $\mathrm{P}(\mathrm{X} \mid \mathrm{Z}), \mathrm{P}(\mathrm{Y} \mid \mathrm{Z})$, and so on, can be obtained through the known prior probability.

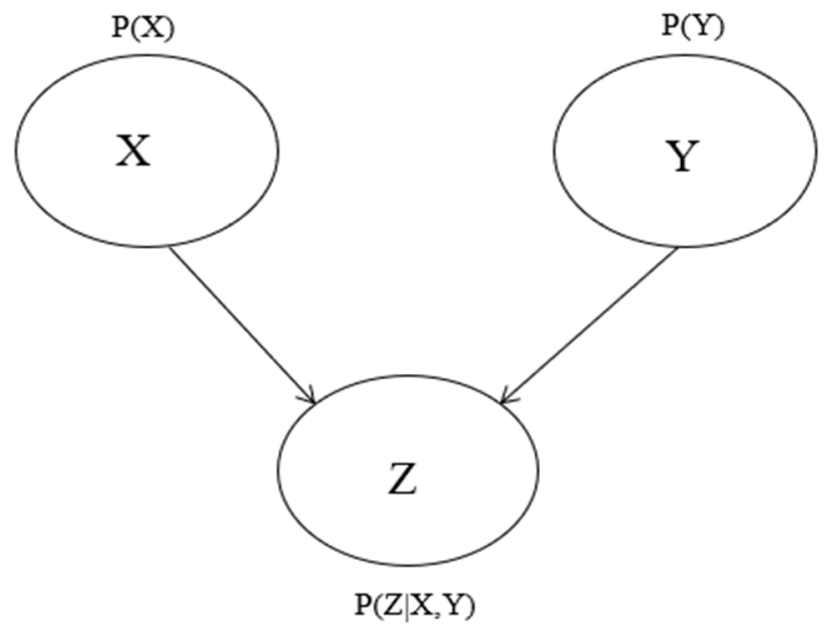

Figure 1. Three variable Bayesian network examples.

A node without a parent is known as a root node, and a node without children is termed as a leaf node. In BNs, nodes with links represent system variables demonstrating uncertain dependencies. Specifically, every node in the graph characterizes an arbitrary variable, whereas the ends between the nodes represent the dependencies of respective random variables [21]. Usually, statistical and computational techniques are used to calculate these provisional dependencies in the chart. Hereafter, BNs merges concepts from statistics, GT, and probability theory [22]; also, Bayesian probabilistic (BP) are used by considering probability as a mark of belief. The BP is less severe, concerning evidence, than the typically utilized probability methods. BN represents a combination of likelihood and GT; thus, it computes dependencies between several information or fact uncertainties [23]. FTA and ATA can be easily transferred to BN because it familiarizes the assemblies of various data, knowledge, functional associations, and approaches; also, it allows for conducting the extensively utilized interpretation for additional analysis [24-27]. In current studies of safety and security co-engineering methods, some factors are not considered, such as parameter optimization and balancing; thus, BN-based techniques can solve these essential issues.

\subsection{Graph Theory}

CIs are a highly interrelated and interdependent system, comprising several components, services, and nodes containing crucial information. There are numerous threats and 
risks that may endanger critical data security and privacy in different CIs. After recognizing the CI risks, the next step for the CI safety and security evaluation is to offer an appropriate model for demonstrating the connection among potential risk sources. The GT model represents the study of mathematical structures applied to prototypical pairwise associations between entities, including nodes and points connected by edges or links. For GT analysis, graphs can be divided into various types, comprising of directed and undirected graphs and connected and disconnected charts, as well as weighted, bipartite, and simple graphs. GT analyzed the connectivity properties for susceptibility, trustworthiness, and risk analysis for several applications, i.e., vehicle networks using different graphs [28-30]. Moreover, topological properties enable techniques, flow-based approaches, and hybrid methods to analyze the reliability, hazards, and safety of systems [31].

There are several benefits of using the graphs model in different sectors. The first and foremost strength of GT is to describe the topological association between several nodes, connecting links between locations (Figure 2). It helps review the connectivity and the degree distribution of every location in a topological space. Those notions are essential for examining the networks. In the case of a spatial network, the vector and geometric characteristics are incredibly beneficial. Vectors properties provide a directional links; for transportation modeling, this property is applied to model flows between locations. The usage of geometrics properties is to insert distance into the model, allowing spatializing the system in Euclidian space. Moreover, GT also offers a description of relations through the graph. Based on the path, i.e., a course among components into the graph, and cycle (a path with a similar origin and endpoint), these characteristics allow for the study of the relationships between various parts of the charts [32-34].

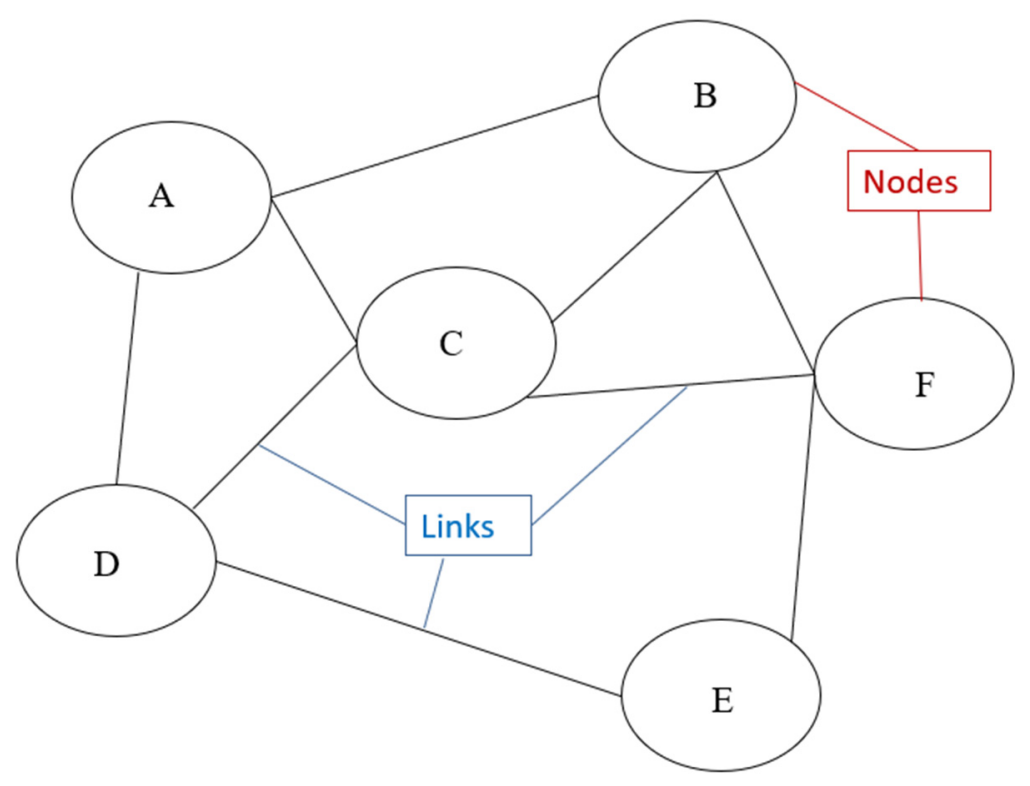

Figure 2. An illustration of graph theory.

In existing studies, GT has been applied in protecting systems [35]. An undirected graph $\mathrm{H}=(\mathrm{U}, \mathrm{F})$ represents a mathematical structure, comprising two sets, $\mathrm{U}$ and $\mathrm{F}$, where $\mathrm{U}=\left\{\mathrm{u}_{1}, \mathrm{u}_{2}, \ldots, \mathrm{u}_{\mathrm{m}}\right\}$ defines the set of nodes. The set of edges is presented by $\mathrm{F}=\left\{\mathrm{f}_{1}\right.$, $\left.f_{2}, \ldots, f_{n}\right\}$. The undirected graph may be useful in presenting CIs or any other complex systems. Furthermore, each subsystem, such as oil and gas, power, and networks, can be exhibited by a subgraph. In GT, each component of the system represents a link, and the nodes are the connections between components, as per the topology of the network. Interdependencies among subsystems are modeled as definite links between end terminals of the two relevant components or subsystems. The CI graph model is supposed to have $\mathrm{m}$ nodes and $\mathrm{n}$ connections [36]. 
GT has become a critical component in various computing applications, such as CI security and network development. However, it is also among the most challenging areas to comprehend and apply for protecting networks, as well as infrastructures. Chung and Lu discussed GT and its real-time implementation in different threat and vulnerability analyses [37]. Ahmat et al. discussed the optimization problems associated with GT and its security applications, using GT concepts to characterize various networks, assess network protocols for multiple scenarios in networking and security, and tools used to generate graphs for demonstrating real-world systems [38]. Shirinivas et al. demonstrated GT's applicability in heterogeneous fields but primarily focused on technical applications that utilize theoretical graph notions [39].

\section{Research Design}

This section presents the fundamental stages for designing this SLR. This study follows the recommendations of the preferred reporting items for systematic reviews and metaanalyses (PRISMA) statement [40]. This design is used to select the security and safety literature, based on BN and GT, to compare and analyze the included studies.

\subsection{Search Querry Process and Research Questions}

In this SLR, ScienceDirect, IEEE Xplore, Web of Sciences, Scopus, and ACM databases were included. Later, a query was asked from identified databases for integrating safety and security, based on Bayesian networks or graph theory (also a combination of both). The search query for this SLR is given below:

("security" AND "safety") AND ("bayesian network" OR "graph theory")

The SLR is a series of associated arguments in support of the research questions (RQs). The RQs of this SLR is stated as follows:

1. Why is the integration of security and safety needed?

2. How have BN- and GT-based methodologies been utilized for security and safety studies in CI?

3. What have been the targeted application domains?

4. What solutions have been developed in the identified studies?

5. How is performance validated for developed techniques and algorithmic solutions?

6. What are the advantages and disadvantages of existing studies?

\subsection{Exclusion and Inclusion Criteria}

This study applies the web application Rayyan QCRI to eliminate duplicate records from different databases and estimate the eligibility of recognized records [41]. Moreover, in this SLR, we used the following exclusion criteria (EC):

(a) Studies that are not focused on the integration of safety and security, based on Bayesian networks or graph theory (also a combination of both).

(b) Studies that merely provide background about the integration of both measures.

(c) Studies that do not develop or design a novel method/approach/model/tool.

In this SLR, we followed specific inclusion criteria for considering studies to be included for analysis. The inclusion steps for this SLR are stated as below:

(a) Published in a conference or journal classified in the identified databases.

(b) The records are identified from January 2011 to September 2020.

(c) Developed a tool or technique for integrating safety and security measures using Bayesian Networks or Graph Theory (also a combination of both approaches).

\section{Results}

This section discusses BN and GT approaches for security and safety to recognize the significant patterns and findings in applying different applications. Moreover, this study analyzes the identified studies, based on organization and classification, citation index, 
applied data source, number of used nodes, application, application sector, threat actor, functionality, implementation scenarios, and validation methodologies.

\subsection{Organization and Classification of Included Studies}

In this study, at the initial stage, 2295 records were identified during the search process, including ScienceDirect $(n=1610)$, Scopus $(n=213)$, ACM $(n=205)$, IEEE Xplore $(\mathrm{n}=193)$, and Web of Science $(\mathrm{n}=74)$. Later, 2093 unique records were recognized, after deleting the duplicate records by applying the screening tool. The title and abstract review recommend that 1853 records be excluded by following the exclusion and inclusion criteria, as elaborated on in Section 3.2. From examining the full-text articles of 240 records, based on the eligibility check process stated in Section 3, 176 were excluded. Merely, 64 papers have discussed the security and safety integration for different $\mathrm{CI}$ applications based on BN and GT and can be considered to perform comparative analysis in this SLR [42-105]. Figure 3 presents a flowchart of the multiple record processing stages in this SLR.
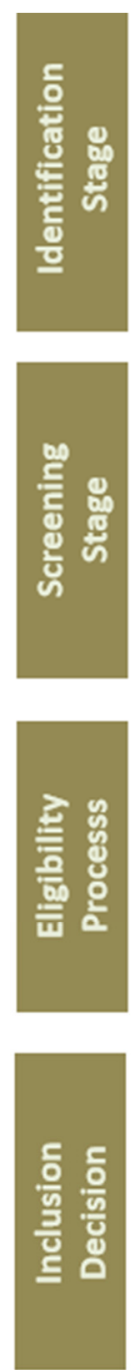
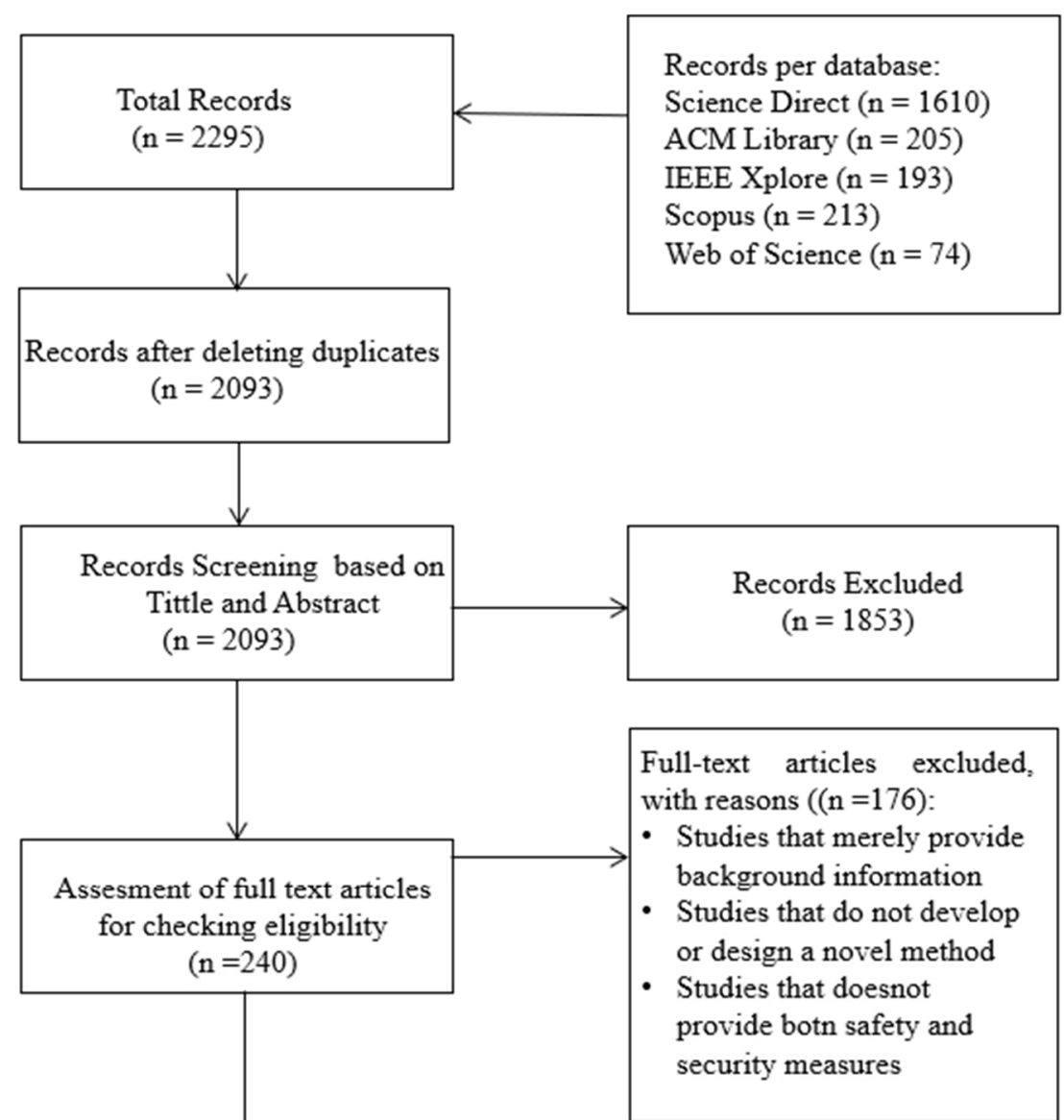

Articles Included for Analysis $(\mathrm{n}=64)$

Figure 3. A flowchart of records processing stages.

The details of the included papers, including study year, number of used references, and category are shown in Table 1 . Figure 4 demonstrates that the journal and conference proceedings are $61 \%$ and $39 \%$ of total articles, respectively. 
Table 1. Details of included articles.

\begin{tabular}{|c|c|c|c|c|}
\hline S.No. & Study & Year & References & Category \\
\hline 1 & Xiaorong et al. [42] & 2020 & 32 & Journal \\
\hline 2 & Lipeng et al. [43] & 2020 & 63 & Journal \\
\hline 3 & Meizhi et al. [44] & 2020 & 44 & Journal \\
\hline 4 & Raditya et al. [45] & 2020 & 40 & Journal \\
\hline 5 & Tai-hua et al. [46] & 2020 & 4 & Conference \\
\hline 6 & Mingjing et al. [47] & 2020 & 42 & Journal \\
\hline 7 & Xiaoxue et al. [48] & 2020 & 38 & Journal \\
\hline 8 & Xin et al. [49] & 2020 & 10 & Conference \\
\hline 9 & Meizhi et al. [50] & 2020 & 40 & Journal \\
\hline 10 & Niamat et al. [51] & 2019 & 78 & Journal \\
\hline 11 & Chengpeng et al. [52] & 2019 & 46 & Journal \\
\hline 12 & Yi et al. [53] & 2019 & 7 & Conference \\
\hline 13 & Barry et al. [54] & 2019 & 48 & Journal \\
\hline 14 & Alexandre et al. [55] & 2019 & 98 & Journal \\
\hline 15 & Sabarathinam et al. [56] & 2019 & 17 & Conference \\
\hline 16 & Seyedmohsen et al. [57] & 2019 & 33 & Journal \\
\hline 17 & Mario et al. [58] & 2019 & 20 & Conference \\
\hline 18 & Chao et al. [59] & 2019 & 61 & Journal \\
\hline 19 & Nima et al. [60] & 2019 & 27 & Journal \\
\hline 20 & Hui et al. [61] & 2019 & 39 & Journal \\
\hline 21 & Xiqiang et al. [62] & 2019 & 6 & Journal \\
\hline 22 & Jamal et al. [63] & 2019 & 30 & Conference \\
\hline 23 & Elvin et al. [64] & 2018 & 27 & Conference \\
\hline 24 & Xiaoyan et al. [65] & 2018 & 31 & Journal \\
\hline 25 & Ying et al. [66] & 2018 & 71 & Journal \\
\hline 26 & Subhojeet et al. [67] & 2017 & 30 & Conference \\
\hline 27 & Huai et al. [68] & 2017 & 64 & Journal \\
\hline 28 & Gabriele et al. [69] & 2017 & 41 & Journal \\
\hline 29 & Zhiqiang et al. [70] & 2017 & 22 & Journal \\
\hline 30 & Jinsoo et al. [71] & 2017 & 23 & Journal \\
\hline 31 & Donya et al. [72] & 2017 & 42 & Journal \\
\hline 32 & Xianyou et al. [73] & 2016 & 15 & Journal \\
\hline 33 & Galizia et al. [74] & 2016 & 13 & Conference \\
\hline 34 & Francesca et al. [75] & 2016 & 21 & Journal \\
\hline 35 & Zhao et al. [76] & 2016 & 8 & Conference \\
\hline 36 & Mark et al. [77] & 2016 & 14 & Journal \\
\hline 37 & Remya et al. [78] & 2016 & 14 & Conference \\
\hline 38 & Xin Chen [79] & 2016 & 25 & Journal \\
\hline 39 & Mark et al. [80] & 2015 & 9 & Conference \\
\hline 40 & Martin et al. [81] & 2015 & 15 & Conference \\
\hline 41 & Jinsoo et al. [82] & 2015 & 29 & Journal \\
\hline 42 & Marco et al. [83] & 2015 & 28 & Journal \\
\hline 43 & Matti et al. [84] & 2015 & 21 & Conference \\
\hline 44 & Xiqiang et al. [85] & 2015 & 6 & Conference \\
\hline 45 & Yongjia et al. [86] & 2015 & 16 & Conference \\
\hline 46 & Kairan et al. [87] & 2015 & 9 & Conference \\
\hline 47 & Amal et al. [88] & 2014 & 19 & Journal \\
\hline 48 & Guannan et al. [89] & 2014 & 36 & Journal \\
\hline 49 & Jiali et al. [90] & 2014 & 17 & Journal \\
\hline 50 & Sher et al. [91] & 2014 & 39 & Journal \\
\hline 51 & LONG et al. [92] & 2014 & 20 & Conference \\
\hline 52 & Zeng Xianfeng [93] & 2014 & 4 & Conference \\
\hline 53 & TIAN et al. [94] & 2013 & 5 & Conference \\
\hline 54 & William et al. [95] & 2013 & 34 & Conference \\
\hline 55 & Jinsoo et al. [96] & 2013 & 23 & Journal \\
\hline 56 & Stefan et al. [97] & 2013 & 15 & Journal \\
\hline 57 & Jingjing et al. [98] & 2013 & 15 & Conference \\
\hline
\end{tabular}


Table 1. Cont.

\begin{tabular}{ccccc}
\hline S.No. & Study & Year & References & Category \\
\hline 58 & John et al. [99] & 2013 & 15 & Conference \\
59 & Heung et al. [100] & 2013 & 21 & Journal \\
60 & Chaze et al. [101] & 2012 & 16 & Conference \\
61 & Mo Ming [102] & 2012 & 4 & Journal \\
62 & Shuliang et al. [103] & 2012 & 68 & Journal \\
63 & Song et al. [104] & 2011 & 23 & Conference \\
64 & André et al. [105] & 2011 & 16 & Journal \\
\hline
\end{tabular}

\section{Classification of Included Articles}

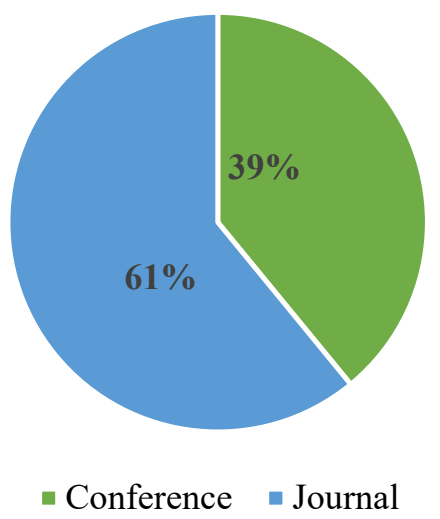

Figure 4. Analysis of identified articles in this SLR.

\subsection{Included Studies Based on GT and BN for Safty and Security}

In recent times, security and safety problems are rapidly converging on different applications, leading to conditions where these closely associated measures that need to be integrated, instead of applied discretely or categorized. Several scholars have developed innovative methodologies to solve risk analysis and evaluation from safety, security, and united security risk management. Table 2 includes existing techniques, based on BN and GT, to resolve safety and security concerns and their respective application sectors.

Table 2. Description of included studies.

\begin{tabular}{cccc}
\hline Study & Application Sector & Technique & \multicolumn{1}{c}{ Description } \\
\hline Xiaorong et al. [42] & Cyber-Physical Systems (CPS) & BN & $\begin{array}{l}\text { The advanced, BN-based method is } \\
\text { proposed to offer a combined solution to } \\
\text { the cyber-to-physical (C2P) risk evaluation } \\
\text { for CPS. Additionally, for verifying the } \\
\text { developed model, two scenarios are } \\
\text { constructed. }\end{array}$ \\
Lipeng et al. [43] & $\begin{array}{l}\text { Public } \\
\text { Sector }\end{array}$ & BN & $\begin{array}{l}\text { A systematic causation model for } \\
\text { evaluating the main reasons for the failure } \\
\text { of security in the 2022 Olympics. }\end{array}$ \\
\hline Meizhi et al. [44] & Maritime & Bndustry & $\begin{array}{l}\text { A BN-based model is proposed for the } \\
\text { dynamic emergency risk estimation. }\end{array}$ \\
\hline Raditya et al. [45] & Industrial Control Systems \\
(ICS) & BN and GT & $\begin{array}{l}\text { A decision-making methodology for } \\
\text { analyzing risk is proposed to examine and } \\
\text { estimate in ICS. }\end{array}$ \\
\hline
\end{tabular}


Table 2. Cont.

\begin{tabular}{|c|c|c|c|}
\hline Study & Application Sector & Technique & Description \\
\hline Tai-hua et al. [46] & $\begin{array}{l}\text { Public } \\
\text { Sector }\end{array}$ & $\mathrm{BN}$ & $\begin{array}{l}\text { To develop public safety and safety } \\
\text { evaluation approach using fuzzy logic and } \\
\text { BN methods. }\end{array}$ \\
\hline Mingjing et al. [47] & Vehicle Transportation & $\mathrm{BN}$ & $\begin{array}{l}\text { Development of } \mathrm{BN} \text { enabled model to } \\
\text { analyze the risk aspects of urban } \\
\text { transportation. }\end{array}$ \\
\hline Xiaoxue et al. [48] & $\begin{array}{l}\text { Maritime } \\
\text { Industry }\end{array}$ & $\mathrm{BN}$ & $\begin{array}{l}\text { A framework is developed for maritime to } \\
\text { offer a balance between resilience and } \\
\text { vulnerability. }\end{array}$ \\
\hline Xin et al. [49] & Education & $\mathrm{BN}$ & $\begin{array}{l}\text { An ideological security evaluation } \\
\text { approach is developed to examine the risk } \\
\text { factors for college students. }\end{array}$ \\
\hline Meizhi et al. [50] & $\begin{array}{l}\text { Maritime } \\
\text { Industry }\end{array}$ & $\mathrm{BN}$ & $\begin{array}{l}\text { To develop and validate the developed } \\
\text { model for pirate attack mitigation by } \\
\text { recognizing the most significant risk } \\
\text { factors. }\end{array}$ \\
\hline Niamat et al. [51] & Smart grid & $\mathrm{BN}$ & $\begin{array}{l}\text { This research quantifies the resilience of } \\
\text { electrical systems to address risks, based on } \\
\text { BN model power. }\end{array}$ \\
\hline Chengpeng et al. [52] & $\begin{array}{l}\text { Maritime } \\
\text { Industry }\end{array}$ & $\mathrm{BN}$ & $\begin{array}{l}\text { To evaluate the risk assessment using fuzzy } \\
\text { rule and BN model in maritime supply } \\
\text { chains. }\end{array}$ \\
\hline Yi et al. [53] & $\begin{array}{l}\text { Maritime } \\
\text { Industry }\end{array}$ & $\mathrm{BN}$ & $\begin{array}{l}\text { To evaluate the possibility of several risks } \\
\text { associated with shipping in navigation } \\
\text { environments. }\end{array}$ \\
\hline Barry et al. [54] & Vehicle Transportation & $\mathrm{BN}$ & $\begin{array}{l}\text { A proactive cyber-risk classification model } \\
\text { is proposed, based on } \mathrm{BN} \text { in transportation. }\end{array}$ \\
\hline Alexandre et al. [55] & Air Transportation & $\mathrm{BN}$ & $\begin{array}{l}\text { This research presented a framework using } \\
\text { BN for the command-and-control support } \\
\text { systems of air transportation. }\end{array}$ \\
\hline Sabarathinam et al. [56] & CPS & $\mathrm{BN}$ & $\begin{array}{l}\text { A framework is developed for the } \\
\text { decision-maker to determine the root cause } \\
\text { of problems in CPSs. }\end{array}$ \\
\hline Seyedmohsen et al. [57] & Vehicle Transportation & $\mathrm{BN}$ & $\begin{array}{l}\text { Development of model, which includes } \\
\text { both qualitative and quantifiable measures } \\
\text { for vehicular electrical systems. }\end{array}$ \\
\hline Mario et al. [58] & Vehicle Transportation & $\mathrm{BN}$ & $\begin{array}{l}\text { A system is proposed for the recognition of } \\
\text { threats in automotive-enabled applications. }\end{array}$ \\
\hline Chao et al. [59] & Chemical Industry & GT & $\begin{array}{l}\text { Integrating security and safety resources to } \\
\text { protect the chemical industry. }\end{array}$ \\
\hline Nima et al. [60] & Process Plants & $\mathrm{BN}$ and GT & $\begin{array}{l}\text { A low-capacity approach is proposed for } \\
\text { process plants, as a temporary mode of } \\
\text { eliminating vulnerabilities. }\end{array}$ \\
\hline Hui et al. [61] & Railways & $\mathrm{BN}$ & $\begin{array}{l}\text { A risk analysis method is proposed for } \\
\text { managing operative risks in the railway. }\end{array}$ \\
\hline Xiqiang et al. [62] & Railways & $\mathrm{BN}$ & $\begin{array}{l}\text { A model is developed to predict and } \\
\text { diagnose risks for urban railway. }\end{array}$ \\
\hline
\end{tabular}


Table 2. Cont.

\begin{tabular}{|c|c|c|c|}
\hline Study & Application Sector & Technique & Description \\
\hline Jamal et al. [63] & Systems of Systems (SoS) & $\mathrm{BN}$ & $\begin{array}{l}\text { Development of an approach to determine } \\
\text { cyber-attacks propagation in SoS. }\end{array}$ \\
\hline Elvin et al. [64] & Vehicle Transportation & $\mathrm{BN}$ & $\begin{array}{l}\text { To develop a framework for trust model } \\
\text { using ML and DL for vehicle } \\
\text { transportation. }\end{array}$ \\
\hline Xiaoyan et al. [65] & Oil and Gas Sector & $\mathrm{BN}$ & $\begin{array}{l}\text { This research identifies risk in the oil and } \\
\text { gas sector by proposing a graphic model } \\
\text { and BN approach. }\end{array}$ \\
\hline Ying et al. [66] & Railways & $\mathrm{BN}$ & $\begin{array}{l}\text { A risk identification method based on } \mathrm{BN} \\
\text { for metro construction is developed. }\end{array}$ \\
\hline Subhojeet et al. [67] & Vehicle Transportation & GT & $\begin{array}{l}\text { A graph enabled based risks recognition } \\
\text { approach in vehicle-vehicle } \\
\text { communication. }\end{array}$ \\
\hline Huai et al. [68] & $\begin{array}{l}\text { Gas } \\
\text { Pipelines }\end{array}$ & GT & $\begin{array}{l}\text { Development of a method to examine the } \\
\text { reliability } \\
\text { in gas pipeline systems. }\end{array}$ \\
\hline Gabriele et al. [69] & Chemical Industry & $\mathrm{BN}$ & $\begin{array}{l}\text { A probabilistic risk assessment method is } \\
\text { developed based on BN to monitor threats } \\
\text { in the chemical industry. }\end{array}$ \\
\hline Zhiqiang et al. [70] & Oil wharf Handling & $\mathrm{BN}$ & $\begin{array}{l}\text { To develop a risk analysis model based on } \\
\text { a static incident approach. }\end{array}$ \\
\hline Jinsoo et al. [71] & Nuclear & $\mathrm{BN}$ & $\begin{array}{l}\text { A methodology is proposed for diagnostic } \\
\text { outcomes from BN model for risk } \\
\text { assessment. }\end{array}$ \\
\hline Donya et al. [72] & Gas and Pipelines & $\mathrm{BN}$ & $\begin{array}{l}\text { A novel methodology is proposed for } \\
\text { vulnerability calculation of gas pipelines. }\end{array}$ \\
\hline Xianyou et al. [73] & $\begin{array}{l}\text { Networks } \\
\text { Security }\end{array}$ & $\mathrm{BN}$ & $\begin{array}{l}\text { Development of vulnerability analysis } \\
\text { method that may eliminate the } \\
\text { cyber-attacks. }\end{array}$ \\
\hline Galizia et al. [74] & Socio-Technical Systems & $\mathrm{BN}$ & $\begin{array}{l}\text { This study aims to examine what factors } \\
\text { could influence sociotechnical systems. }\end{array}$ \\
\hline Francesca et al. [75] & Chemical Industry & $\mathrm{BN}$ & $\begin{array}{l}\text { The developed approach addresses the } \\
\text { vulnerability evaluation using BN model. }\end{array}$ \\
\hline Zhao et al. [76] & Navigation Environment & $\mathrm{BN}$ & $\begin{array}{l}\text { Establishment of an index system by } \\
\text { integrating BN with fuzzy theory to offer } \\
\text { safety evaluation. }\end{array}$ \\
\hline Mark et al. [77] & Chemical Industry & $\mathrm{BN}$ & $\begin{array}{l}\text { Development of vulnerability analysis } \\
\text { approach methodology for monitoring } \\
\text { intentional attacks. }\end{array}$ \\
\hline Remya et al. [78] & $\begin{array}{l}\text { Unmanned Aerial Vehicles } \\
\text { (UAV) }\end{array}$ & $\mathrm{BN}$ & $\begin{array}{l}\text { A technique to solve issues related to } \\
\text { software risks and failures are developed } \\
\text { by using BayesiaLab. }\end{array}$ \\
\hline Xin Chen [79] & Complex Systems & GT & $\begin{array}{l}\text { A polynomial-time system is proposed to } \\
\text { recognize critical nodes for ensuring } \\
\text { security in complex systems, such as the } \\
\text { power and energy sectors. }\end{array}$ \\
\hline
\end{tabular}


Table 2. Cont.

\begin{tabular}{|c|c|c|c|}
\hline Study & Application Sector & Technique & Description \\
\hline Mark et al. [80] & Petroleum Plants & $\mathrm{BN}$ & $\begin{array}{l}\text { Development of extended risk analysis } \\
\text { methods at various stages of plants to } \\
\text { ensure unauthorized access. }\end{array}$ \\
\hline Martin et al. [81] & $\begin{array}{l}\text { Maritime } \\
\text { Industry }\end{array}$ & GT & $\begin{array}{l}\text { This study develops an approach for } \\
\text { validating the vulnerability in the maritime } \\
\text { sector. }\end{array}$ \\
\hline Jinsoo et al. [82] & Nuclear & $\mathrm{BN}$ & $\begin{array}{l}\text { To develop a model for evaluating security } \\
\text { for the nuclear domain in a unified way. }\end{array}$ \\
\hline Marco et al. [83] & Railways & $\mathrm{BN}$ & $\begin{array}{l}\text { Development of methodology for } \\
\text { transferring attacks trees into BNs. }\end{array}$ \\
\hline Matti et al. [84] & Mobile Networks & $\mathrm{BN}$ & $\begin{array}{l}\text { Establishment of probabilistic risk } \\
\text { evaluation approach for risk assessment } \\
\text { and sensitivity analysis. }\end{array}$ \\
\hline Xiqiang et al. [85] & Railways & $\mathrm{BN}$ & $\begin{array}{l}\text { To develop BN enabled model for train } \\
\text { control center that can be quantifiable for } \\
\text { safety analysis in railway. }\end{array}$ \\
\hline Yongjia et al. [86] & $\begin{array}{l}\text { Cognitive Radio Networks } \\
\text { (CRNs) }\end{array}$ & $\mathrm{BN}$ & $\begin{array}{l}\text { Establishing an innovative system to } \\
\text { diagnose and protect from malicious } \\
\text { attacks. }\end{array}$ \\
\hline Kairan et al. [87] & Vehicle Transportation & $\mathrm{BN}$ & $\begin{array}{l}\text { Development of transportation security } \\
\text { evaluation method to estimate a real-world } \\
\text { mountainous expressway. }\end{array}$ \\
\hline Amal et al. [88] & $\begin{array}{l}\text { Maritime } \\
\text { Industry }\end{array}$ & $\mathrm{BN}$ & $\begin{array}{l}\text { A novel solution related to offshore piracy } \\
\text { is proposed to characterize threats and } \\
\text { probable targets. }\end{array}$ \\
\hline Guannan et al. [89] & Software & $\mathrm{BN}$ & $\begin{array}{l}\text { An estimation model is proposed for } \\
\text { internet-based software applications. }\end{array}$ \\
\hline Jiali et al. [90] & $\begin{array}{l}\text { Maritime } \\
\text { Industry }\end{array}$ & $\mathrm{BN}$ & $\begin{array}{l}\text { To develop a fuzzy enabled BN system in } \\
\text { shipping to evaluate the security of } \\
\text { passengers. }\end{array}$ \\
\hline Sher et al. [91] & Railways & GT & $\begin{array}{l}\text { Incorporation of mobile agent notions with } \\
\text { Petri nets offers one-dimensional control, } \\
\text { which raises the safety of the train system. }\end{array}$ \\
\hline LONG et al. [92] & Smart Grid & $\mathrm{BN}$ & $\begin{array}{l}\text { An integrated method of FTA and BN is } \\
\text { developed for analyzing risks in power } \\
\text { systems. }\end{array}$ \\
\hline Zeng Xianfeng [93] & Railways & $\mathrm{BN}$ & $\begin{array}{l}\text { To develop a security evaluation method } \\
\text { using BN model to improve train } \\
\text { equipment and repair and maintenance } \\
\text { work reliability. }\end{array}$ \\
\hline TIAN et al. [94] & Water Traffic System & $\mathrm{BN}$ & $\begin{array}{l}\text { This research develops a system that can } \\
\text { monitor the safety issues associated with } \\
\text { water traffic to realize the initial warning } \\
\text { efficiently. }\end{array}$ \\
\hline William et al. [95] & $\begin{array}{l}\text { Networks } \\
\text { Security }\end{array}$ & $\mathrm{BN}$ & $\begin{array}{l}\text { An incorporated framework is developed } \\
\text { to monitor for computing a mean time to } \\
\text { compromise the system by the } \\
\text { known-unknown vulnerability. }\end{array}$ \\
\hline
\end{tabular}


Table 2. Cont.

\begin{tabular}{|c|c|c|c|}
\hline Study & Application Sector & Technique & Description \\
\hline Jinsoo et al. [96] & Nuclear & $\mathrm{BN}$ & $\begin{array}{l}\text { To establish a risk investigation approach } \\
\text { for instrumentation and control (I and C) } \\
\text { for identifying mitigating vulnerabilities. }\end{array}$ \\
\hline Stefan et al. [97] & Vehicle Transportation & GT & $\begin{array}{l}\text { Three graph-based protocols were } \\
\text { developed, by means of wide-ranging } \\
\text { simulations, to detect insider threats. }\end{array}$ \\
\hline Jingjing et al. [98] & Railways & $\mathrm{BN}$ & $\begin{array}{l}\text { To propose an approach to meet the } \\
\text { necessities of accuracy in high safety for } \\
\text { the train control system for a fault } \\
\text { diagnosis system. }\end{array}$ \\
\hline John et al. [99] & Air Transportation & GT & $\begin{array}{l}\text { Development of method using game theory } \\
\text { and GT concepts and graph theory for } \\
\text { security risk mitigation. }\end{array}$ \\
\hline Heung et al. [100] & Nuclear & $\mathrm{BN}$ & $\begin{array}{l}\text { This study analytically modeled } \\
\text { management approach, which offers the } \\
\text { progress of safety-critical software. }\end{array}$ \\
\hline Chaze et al. [101] & Maritime Industry & $\mathrm{BN}$ & $\begin{array}{l}\text { This study presents the architecture based } \\
\text { on incorporated BNs for its feedback } \\
\text { planning. }\end{array}$ \\
\hline Mo Ming [102] & $\begin{array}{l}\text { Network } \\
\text { Security }\end{array}$ & GT & $\begin{array}{l}\text { An integrated GT approach is developed to } \\
\text { have a safety evaluation in the network } \\
\text { security domain. }\end{array}$ \\
\hline Shuliang et al. [103] & Smart Grid & GT & $\begin{array}{l}\text { A framework is proposed to investigate the } \\
\text { susceptibilities in interdependent systems. }\end{array}$ \\
\hline Song et al. [104] & Asian Games & $\mathrm{BN}$ & $\begin{array}{l}\text { The proposed } \mathrm{BN} \text { model accomplishes fire } \\
\text { risk evaluation along with conducting fast } \\
\text { disaster condition valuation. }\end{array}$ \\
\hline André et al. [105] & Medical & $\mathrm{BN}$ and GT & $\begin{array}{l}\text { This study presents an application for risk } \\
\text { mitigation in ventricular-enabled devices. }\end{array}$ \\
\hline
\end{tabular}

\subsection{Citation Index of Included Studies}

In this SLR, the citation index is adapted to evaluate the research quality of each included technique, i.e., BN or GT or unified BN and GT. The citation index represents the number of citations of the included studies as per Google Scholar, accessed on 20th November 2020, as revealed in Table 3. The most extensive cited studies were 139 citations for Shuliang et al. [103], 76 citations are Jinsoo et al. [82], and 60 citations for Huai et al. [68], which are published in 2012, 2015, and 2017, respectively. Whereas the following studies have not received any citations: Tai-hua et al. [46], Xiaoxue et al. [48], and Xin et al. [49] (published in 2020), Sabarathinam et al. [56], Xiqiang et al. [62], and Jamal et al. [63] (published in 2019), Zhao et al. [76] (published in 2016), Jiali et al. [90], and Zeng Xianfeng [93] (published in 2014), and Mo Ming [102] (published in 2012).

Table 3. Citation index and data sources of included studies.

\begin{tabular}{ccccc}
\hline Study & Citations & Data Source & Nodes & Applicability \\
\hline Xiaorong et al. [42] & 2 & EK, ED & 9 & Risk Management \\
Lipeng et al. [43] & 2 & EK, ED & 31 & Holistic Event \\
Investigation \\
Meizhi et al. [44] & 2 & EK, ED & 15 & Risk Management \\
Raditya et al. [45] & 1 & ED & 8 & Risk Management \\
Tai-hua et al. [46] & 0 & EK & & Risk Management \\
\hline
\end{tabular}


Table 3. Cont.

\begin{tabular}{|c|c|c|c|c|}
\hline Study & Citations & Data Source & Nodes & Applicability \\
\hline Mingjing et al. [47] & 1 & EK, ED & 11 & Risk Management \\
\hline Xiaoxue et al. [48] & 0 & EK & 16 & $\begin{array}{l}\text { Vulnerability } \\
\text { Assessment }\end{array}$ \\
\hline Xin et al. [49] & 0 & ED & & Risk Management \\
\hline Meizhi et al. [50] & 1 & EK, ED & 14 & Risk Management \\
\hline Niamat et al. [51] & 30 & $\mathrm{EK}, \mathrm{ED}$ & 5 & $\begin{array}{c}\text { Resilience } \\
\text { Quantification }\end{array}$ \\
\hline Chengpeng et al. [52] & 32 & EK, ED & 11 & Risk Management \\
\hline Yi et al. [53] & 1 & EK, ED & 24 & Risk Management \\
\hline Barry et al. [54] & 48 & EK, ED & 51 & Risk Management \\
\hline Alexandre et al. [55] & 4 & ED & 13 & $\begin{array}{l}\text { Cyber Impact } \\
\text { Assessment }\end{array}$ \\
\hline Sabarathinam et al. [56] & 0 & $\mathrm{EK}, \mathrm{ED}$ & 8 & Root Cause Analysis \\
\hline Seyedmohsen et al. [57] & 37 & EK, ED & 6 & Risk Management \\
\hline Mario et al. [58] & 7 & ED & 5 & Intrusion Detection \\
\hline Chao et al. [59] & 30 & ED & 4 & Risk Management \\
\hline Nima et al. [60] & 8 & ED & 6 & $\begin{array}{l}\text { Vulnerability } \\
\text { Assessment }\end{array}$ \\
\hline Hui et al. [61] & 4 & ED & 24 & Risk Management \\
\hline Xiqiang et al. [62] & 0 & EK, ED & 19 & Risk Management \\
\hline Jamal et al. [63] & 0 & EK & 8 & Risk Management \\
\hline Elvin et al. [64] & 10 & ED & & Trust Computation \\
\hline Xiaoyan et al. [65] & 25 & ED & 40 & Risk Management \\
\hline Ying et al. [66] & 16 & EK, ED & 31 & Risk Management \\
\hline Subhojeet et al. [67] & 7 & ED & 6 & Anomaly Detection \\
\hline Huai et al. [68] & 60 & EK, ED & 53 & Reliability Assessment \\
\hline Gabriele et al. [69] & 16 & EK & 8 & Risk Management \\
\hline Zhiqiang et al. [70] & 4 & ED & 47 & Risk Management \\
\hline Jinsoo et al. [71] & 27 & ED & 13 & Risk Management \\
\hline Donya et al. [72] & 17 & EK & 30 & $\begin{array}{l}\text { Vulnerability } \\
\text { Assessment }\end{array}$ \\
\hline Xianyou et al. [73] & 3 & ED & 20 & $\begin{array}{l}\text { Vulnerability } \\
\text { Assessment }\end{array}$ \\
\hline Galizia et al. [74] & 4 & EK & 12 & Risk Management \\
\hline Francesca et al. [75] & 12 & EK, ED & 8 & $\begin{array}{l}\text { Vulnerability } \\
\text { Assessment }\end{array}$ \\
\hline Zhao et al. [76] & 0 & EK & 24 & Risk Management \\
\hline Mark et al. [77] & 9 & EK, ED & 8 & $\begin{array}{l}\text { Vulnerability } \\
\text { Assessment }\end{array}$ \\
\hline Remya et al. [78] & 2 & EK, ED & 6 & Safety Assessment \\
\hline Xin Chen [79] & 6 & EK & 60 & $\begin{array}{l}\text { Vulnerability } \\
\text { Assessment }\end{array}$ \\
\hline Mark et al. [80] & 4 & EK, ED & 17 & Risk Management \\
\hline Martin et al. [81] & 1 & ED & 3 & $\begin{array}{l}\text { Vulnerability } \\
\text { Assessment }\end{array}$ \\
\hline Jinsoo et al. [82] & 76 & ED & 64 & $\begin{array}{l}\text { Vulnerability } \\
\text { Assessment }\end{array}$ \\
\hline Marco et al. [83] & 22 & EK & 10 & Risk Management \\
\hline Matti et al. [84] & 1 & EK & 5 & Risk Management \\
\hline Xiqiang et al. [85] & 3 & EK & 47 & Risk Management \\
\hline Yongjia et al. [86] & 7 & ED & 4 & Attacks Analysis \\
\hline Kairan et al. [87] & 4 & EK & 36 & Risk Management \\
\hline Amal et al. [88] & 60 & EK & 20 & Risk Management \\
\hline Guannan et al. [89] & 1 & ED & 20 & Risk Management \\
\hline Jiali et al. [90] & 0 & EK, ED & 58 & Risk Management \\
\hline Sher et al. [91] & 17 & ED & 14 & Software Verification \\
\hline LONG et al. [92] & 2 & EK & 4 & Risk Management \\
\hline Zeng Xianfeng [93] & 0 & ED & 22 & Safety Assessment \\
\hline
\end{tabular}


Table 3. Cont.

\begin{tabular}{ccccc}
\hline Study & Citations & Data Source & Nodes & Applicability \\
\hline TIAN et al. [94] & 1 & ED & 12 & Water Traffic \\
William et al. [95] & 33 & ED & 20 & Management \\
Jinsoo et al. [96] & 17 & ED & 16 & Risk Management \\
Stefan et al. [97] & 49 & ED & 8 & Attack Analysis \\
Jingjing et al. [98] & 10 & EK, ED & 7 & Fault Analysis \\
John et al. [99] & 3 & EK & 16 & Risk Management \\
Heung et al. [100] & 32 & EK, ED & 8 & Fault Analysis \\
Chaze et al. [101] & 11 & EK & 4 & Risk Management \\
Mo Ming [102] & 0 & ED & 6 & Attack Analysis \\
Shuliang et al. [103] & 139 & ED & 182 & Vulnerability \\
Song et al. [104] & 1 & EK, ED & 45 & Assessment \\
André et al. [105] & 15 & ED & 4 & Risk Management \\
\hline
\end{tabular}

However, the record number of included articles per year is reported in Figure 5, which demonstrates the research trend of applying GT and BN to implement safety and security, based on the included studies. The analysis suggests that scholars have been publishing more articles, addressing united safety and security aspects, in the last two years. From 2019 and 2020, 13 (9 BN, 1 GT, 1GT, and BN), and 9 (8 BN, 1 BN, and GT) papers are included in this SLR, respectively.

\section{Included Articles per Year}

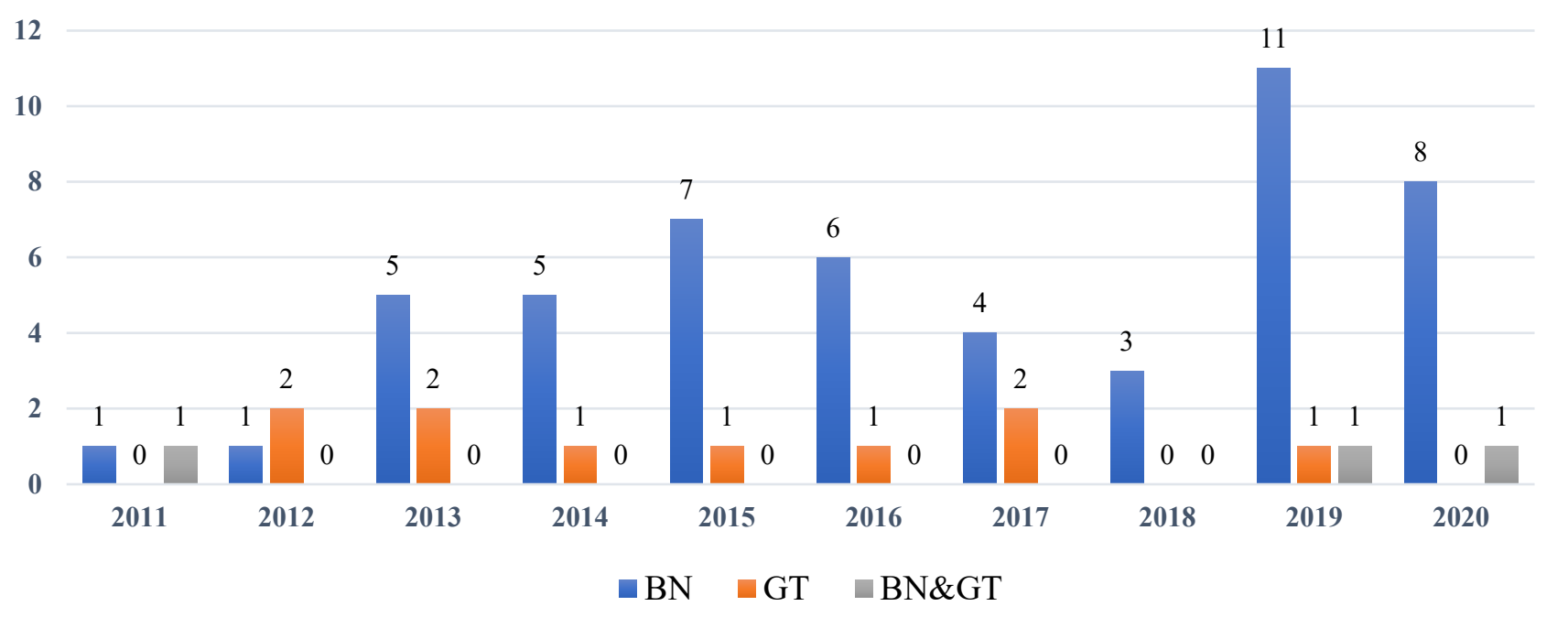

Figure 5. Research trend of included studies.

\subsection{Data Sources and Number of Nodes Used to Construct BN/GT}

The BN and GT play a significant role in predicting and unintentionally diagnosing failures and targeted risks by using numerous tools and models, based on the information collected from the system expert's knowledge (EK) and/or from empirical data (ED). EK represents the opinions collected by interviewing the system or domain expert, and ED is the historical or experimental data gathered by real-time scenarios or the literature [50-54]. It is revealed in existing studies that a reliable strategy can be attained for the developed model by applying collective EK and ED. Figure 6 demonstrates that 26 out of 64 of the included studies used only ED to developed BN or GT approaches. Whereas 16 out of 64 applied EK and 26 out of 64 of included studies that utilized both ED and EK to develop 
GT- or BN-enabled models. It is observed that 3 out of 64 of the included studies were based on integrating GT and BN for addressing united security and safety measures, and these studies employed ED analysis for the system development. Though 10 out of 64 included studies were based on GT, in which 7 uses ED, 2 applies EK, and 1 utilizes both. Besides, BN models are applied in 51 out of 64 studies, which categorize as EK (14), ED (16), and collective EK and ED (21).

\section{Data Sources of Included Studies}

30

25

20

15

10

5

0

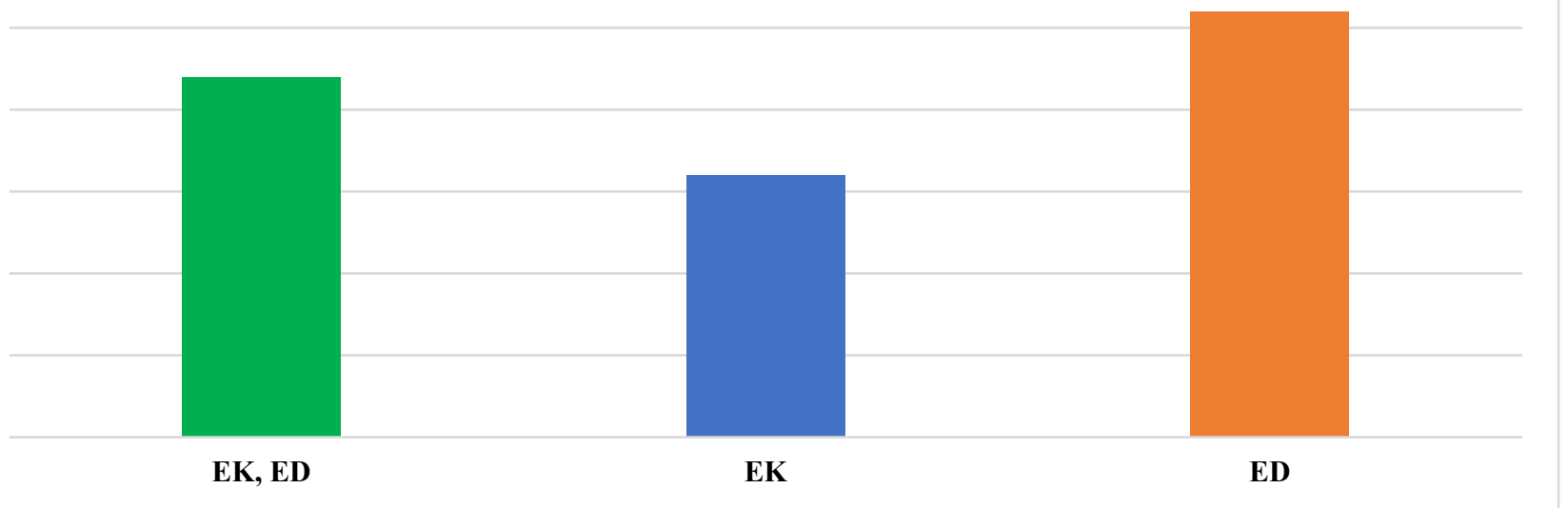

Figure 6. The used data sources for developing BN and GT models.

Several nodes are linked together to represent BN or GT enabled systems for assessing risks and vulnerabilities in different applications. Moreover, the quantity of nodes can be utilized to represent the model complexity of the system. A large number of nodes may reflect the incapacitated association between input and output nodes by introducing in-between layers between source and destination. Chockalingam et al. [106] stated that it is suggested to have a total number of nodes in BN models less than 40. In this SLR, it is observed that 43 out of $51 \mathrm{BN}$-based model have used less than 40 nodes. However, the remaining eight have used equal or more than 40, including Xiaoyan et al. [65], Song et al. [104], Zhiqiang et al. [70], Xiqiang et al. [85], Barry et al. [54], Jiali et al. [90], Remya et al. [78], and Jinsoo et al. [82], 40, 45, 47, 47, 51, 58, 60, and 64, respectively. However, all models that utilized GT and BN simultaneously have used less than 40 nodes in the developed system. Moreover, it is also noticed that 2 out of 10 GT-based approaches have utilized more than 40 nodes comprising Huai et al. [68] and Shuliang et al. [103], 53 and 182, respectively. Whereas, remaining 8 included studies of GT employ less than 40 nodes.

\subsection{Applicability, Threat Actor, and Implementation Criteria}

The characteristic applicability is used to comprehend the type of evaluation that is acquired from the developed methodologies. In this SLR, it is observed that 37 out of 64 studies ensure risk management in the proposed system for identifying, analyzing, evaluating, and treating loss exposures, as well as monitoring risk control and financial resources, to mitigate the adverse effects of loss. There are three main stages: identifying, assessing, and evaluating risk. The procedure for assessing risk is the main element in the risk management process. Generally, there are two sorts of risk assessment approaches, including quantitative and qualitative strategies. The qualitative assessment techniques primarily rely on proficient knowledge and attention for revealing the risks. In contrast, the quantitative assessment methods can compute the risk value of the system and emphasize the system's quantitative performance under the risks.

In general, the quantitative methods are chosen to conduct risk analysis and assessment, owing to the accurate explanations of system risks that can optimize the distribution 
of protected resources. Whereas 10 out of 64 perform the task of vulnerability assessment for evaluating whether the network is vulnerable to any identified vulnerabilities, allocates severity levels to those susceptibilities, and recommends remediation or mitigation, if and whenever required. Moreover, 3 out of 64,2 out of 64 , and 2 out of 64 perform attack analysis, fault analysis, and safety assessment, respectively. Besides, 10 out 64 studies perform distinct functionalities, comprising of Lipeng et al. [43], Niamat et al. [51], Alexandre et al. [55], Sabarathinam et al. [56], Mario C et al. [58], Elvin et al. [64], Subhojeet et al. [67], Huai et al. [68], Sher et al. [91], and TIAN et al. [94], holistic event investigation, resilience quantification, cyber impact assessment, root cause analysis, intrusion detection, trust computation, anomaly detection, reliability assessment, software verification, and water traffic management, respectively.

In this SLR, the threat actor is used to identifying that the included studies help prevent the attack. It is observed that the threat actor is classified into two types, such as external and internal. It is observed from Figure 7 that 7 out of 64 and 2 out of 64 studies have mentioned that the developed methodology is applicable against external and internal threats, respectively. Moreover, 2 out 64 developed approaches help prevent both internal and external threats. However, the remaining 53 included articles have not specified any particular kind of threat but rather concentrated on warnings and alarms, which may be suitable for various possible threats.

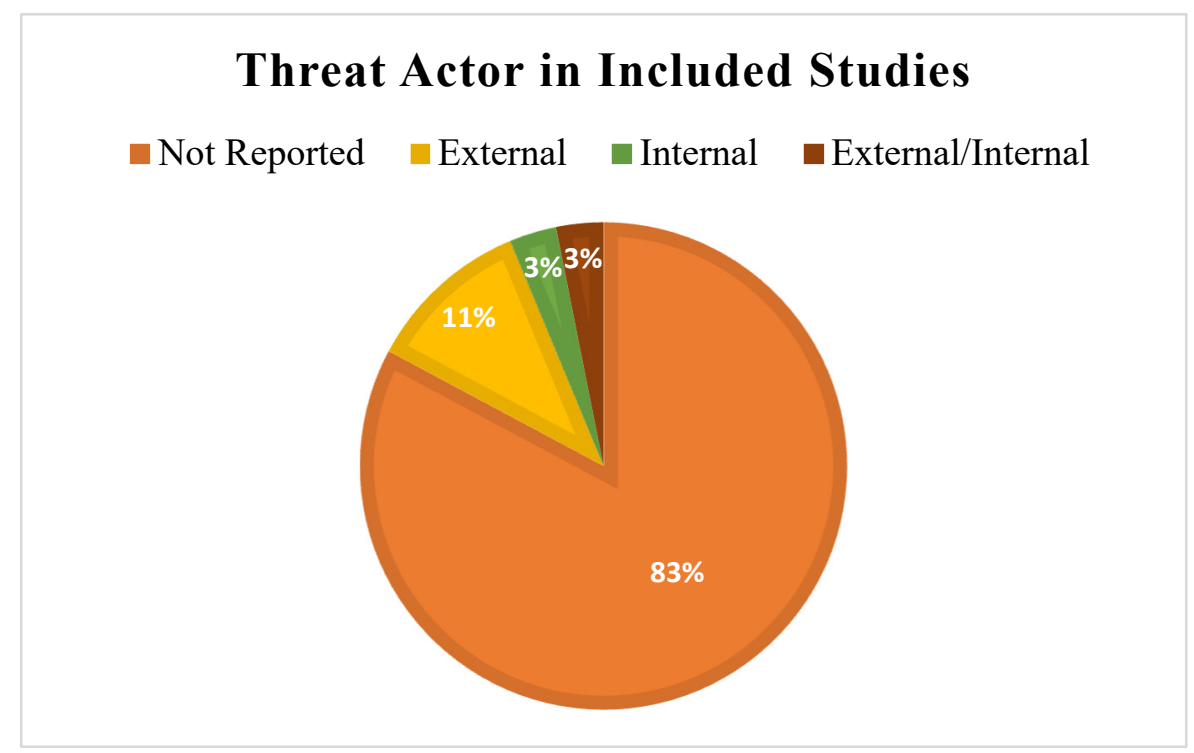

Figure 7. Threat Actor in Included Studies.

Implementing GT- or BN-based models is vital to measure network performance, transform strategic plans to monitor failures and risks in the system, and apply the necessary actions to achieve integrated safety and security for different applications. During the review process, it is observed that GT- or BN-based development scenarios are an association of nodes, modules, and the implementation subsystems. This SLR suggests that $42 \%, 31 \%$, and $27 \%$ of the included studies performed simulated, real-time, and preliminary analysis, respectively, as shown in Table 4.

Table 4. Threat Actor and Implementation Criteria of Included Studies.

\begin{tabular}{ccc}
\hline Study & Implementation Criteria & Threat Actor \\
\hline Xiaorong et al. [42] & Simulation & Not Specified \\
Lipeng et al. [43] & Simulation & Outsider \\
Meizhi et al. [44] & Simulation & Not Specified \\
Raditya et al. [45] & Real-time & Insider \\
Tai-hua et al. [46] & Real-time & Outsider \\
\hline
\end{tabular}


Table 4. Cont.

\begin{tabular}{|c|c|c|}
\hline Study & Implementation Criteria & Threat Actor \\
\hline Mingjing et al. [47] & Simulation & Not Specified \\
\hline Xiaoxue et al. [48] & Real-time & Not Specified \\
\hline Xin et al. [49] & Real-time & Not Specified \\
\hline Meizhi et al. [50] & Preliminary & Not Specified \\
\hline Niamat et al. [51] & Preliminary & Outsider, Insider \\
\hline Chengpeng et al. [52] & Real-time & Not Specified \\
\hline Yi et al. [53] & Simulation & Not Specified \\
\hline Barry et al. [54] & Preliminary & Not Specified \\
\hline Alexandre et al. [55] & Simulation & Outsider \\
\hline Sabarathinam et al. [56] & Simulation & Not Specified \\
\hline Seyedmohsen et al. [57] & Simulation & Not Specified \\
\hline Mario et al. [58] & Simulation & Not Specified \\
\hline Chao et al. [59] & Preliminary & Not Specified \\
\hline Nima et al. [60] & Real-time & Outsider \\
\hline Hui et al. [61] & Real-time & Outsider \\
\hline Xiqiang et al. [62] & Real-time & Not Specified \\
\hline Jamal et al. [63] & Simulation & Not Specified \\
\hline Elvin et al. [64] & Preliminary & Not Specified \\
\hline Xiaoyan et al. [65] & Real-time & Not Specified \\
\hline Ying et al. [66] & Real-time & Outsider \\
\hline Subhojeet et al. [67] & Simulation & Not Specified \\
\hline Huai et al. [68] & Simulation & Not Specified \\
\hline Gabriele et al. [69] & Preliminary & Not Specified \\
\hline Zhiqiang et al. [70] & Simulation & Not Specified \\
\hline Jinsoo et al. [71] & Real-time & Insider \\
\hline Donya et al. [72] & Preliminary & Not Specified \\
\hline Xianyou et al. [73] & Preliminary & Not Specified \\
\hline Galizia et al. [74] & Simulation & Not Specified \\
\hline Francesca et al. [75] & Simulation & Outsider \\
\hline Zhao et al. [76] & Real-time & Not Specified \\
\hline Mark et al. [77] & Real-time & Outsider, Insider \\
\hline Remya et al. [78] & Simulation & Not Specified \\
\hline Xin Chen [79] & Simulation & Not Specified \\
\hline Mark et al. [80] & Preliminary & Not Specified \\
\hline Martin et al. [81] & Preliminary & Not Specified \\
\hline Jinsoo et al. [82] & Real-time & Not Specified \\
\hline Marco et al. [83] & Simulation & Not Specified \\
\hline Matti et al. [84] & Simulation & Not Specified \\
\hline Xiqiang et al. [85] & Real-time & Not Specified \\
\hline Yongjia et al. [86] & Preliminary & Not Specified \\
\hline Kairan et al. [87] & Preliminary & Not Specified \\
\hline Amal et al. [88] & Preliminary & Not Specified \\
\hline Guannan et al. [89] & Simulation & Not Specified \\
\hline Jiali et al. [90] & Real-time & Not Specified \\
\hline Sher et al. [91] & Real-time & Not Specified \\
\hline LONG et al. [92] & Simulation & Not Specified \\
\hline Zeng Xianfeng [93] & Simulation & Not Specified \\
\hline TIAN et al. [94] & Real-time & Not Specified \\
\hline William et al. [95] & Simulation & Not Specified \\
\hline Jinsoo et al. [96] & Simulation & Not Specified \\
\hline Stefan et al. [97] & Simulation & Insider \\
\hline Jingjing et al. [98] & Simulation & Not Specified \\
\hline John et al. [99] & Preliminary & Not Specified \\
\hline Heung et al. [100] & Preliminary & Not Specified \\
\hline Chaze et al. [101] & Simulation & Not Specified \\
\hline Mo Ming [102] & Real-time & Not Specified \\
\hline Shuliang et al. [103] & Simulation & Not Specified \\
\hline Song et al. [104] & Simulation & Not Specified \\
\hline André et al. [105] & Real-time & Not Specified \\
\hline
\end{tabular}




\section{Discussion}

This section includes answers based on comparative analysis of included articles to find solutions for given RQs in Section 2.

\subsection{Why Is the Integration of Security and Safety Needed?}

In recent times, computer networks have been widely applied in several applications; any failure in these systems could have critical outcomes. There are various hypotheses about the characteristics such crucial systems must maintain, and the methods employed to protect them. Two such attributes are security and safety. Nevertheless, modern designs are usually needed to meet these two attributes simultaneously. Considering safety and security, common goals are needed to protect peoples or systems; therefore, safety-critical assets are considered.

Martin et al. [81] stated that the marine industry is a critical sector, and it is essential to combine safety and security concerns on the sea. The integration of two aspects concentrates on analyzing the energy supply vulnerabilities and introduces a methodology to evaluate the system's exposure using the spatial composition of maritime regions. This study contributes a GT-based model for offering safety and security in a maritime territory. Indeed, the developed model utilizes links, such as roads and ports, as nodes. Matti et al. [84] demonstrate the significance of public safety and security (PSS) in mobile networks. In this study, a risk evaluation model, using BN, is proposed for the current PSS telecommunication services.

\subsection{How Have Bayesian Network- and Graph Theory-Based Methodologies Been Utilized for} Security and Safety Studies in CI?

This RQ assists in knowing which models are used for safety and security integration, functionalities, and applicability. In this SLR, it is observed that $80 \%, 15 \%$, and $5 \%$ of the included studies use BN and GT, as well as both GT and BN, respectively, as shown in Figure 8 .

\section{Unified Security and Safety based on BN and GT}

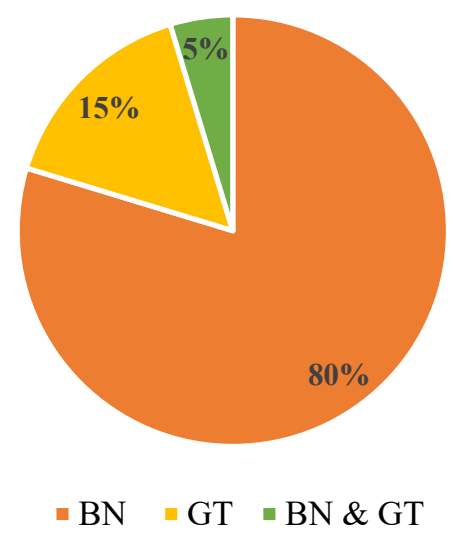

Figure 8. Characterization of BN and GT models in included studies.

From Figure 9, it is observed that the developed models based on BN or GT in included studies were utilized to have two sorts of purposes, including diagnosis and prediction. The term diagnosis represents identifying the nature or cause of the incidents or other risks in the systems. In contrast, the prediction is associated with forecasting potential cyber threats in the respective CIs. This study identifies that $48 \%$ of approaches perform a diagnosis of the risks in different applications. However, $36 \%$ and $16 \%$ of papers ensure performance prediction and both prediction and diagnosis, respectively. 


\section{Functionality of Included Studies}

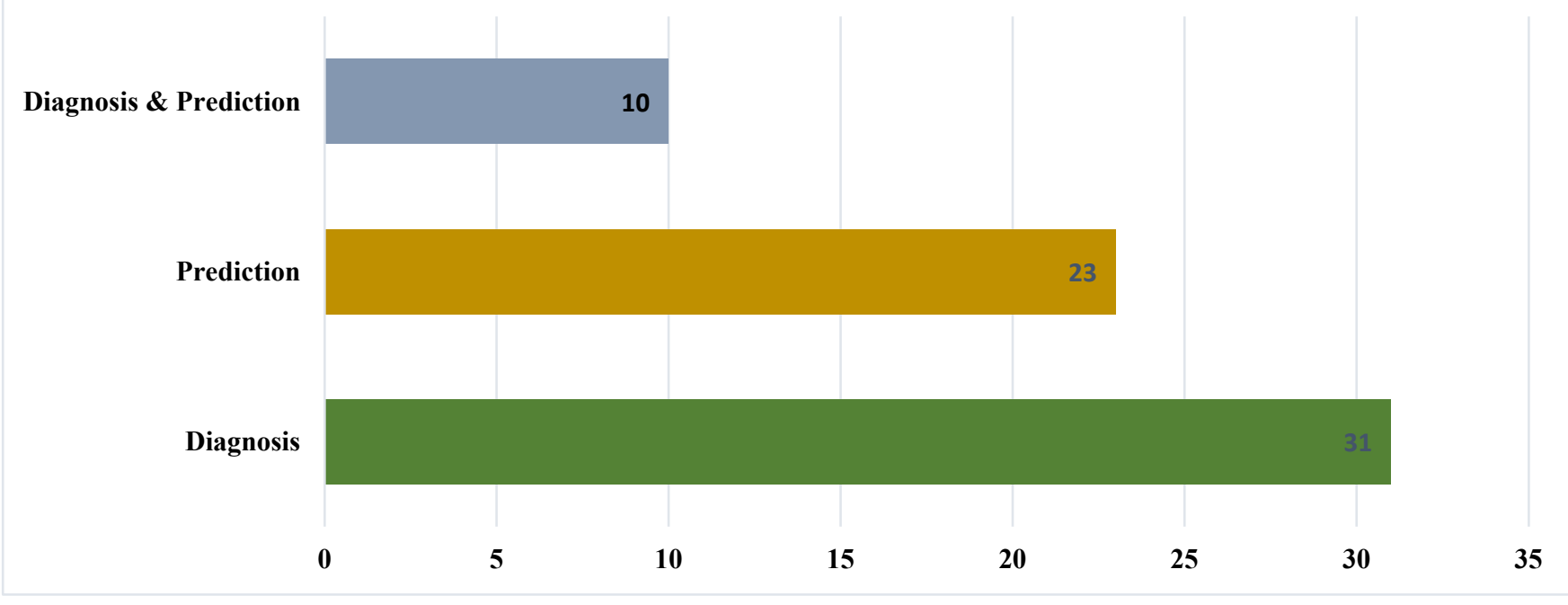

Figure 9. Functionality of included studies.

However, the applicability of included studies is demonstrated in Figure 10. The key applicability area for integrating safety and security using GT or BN is risk assessment $(60 \%)$ of included studies. It is observed that vulnerability assessment, attack analysis, safety analysis, and fault analysis are $16 \%, 5 \%, 3 \%$, and 3\%, respectively. Moreover, the applicability of approximately $1 \%$ of total studies is in holistic event investigation, resilience quantification, cyber impact assessment, root cause analysis, intrusion detection, trust computation, anomaly detection, reliability assessment, software verification, and water traffic management.

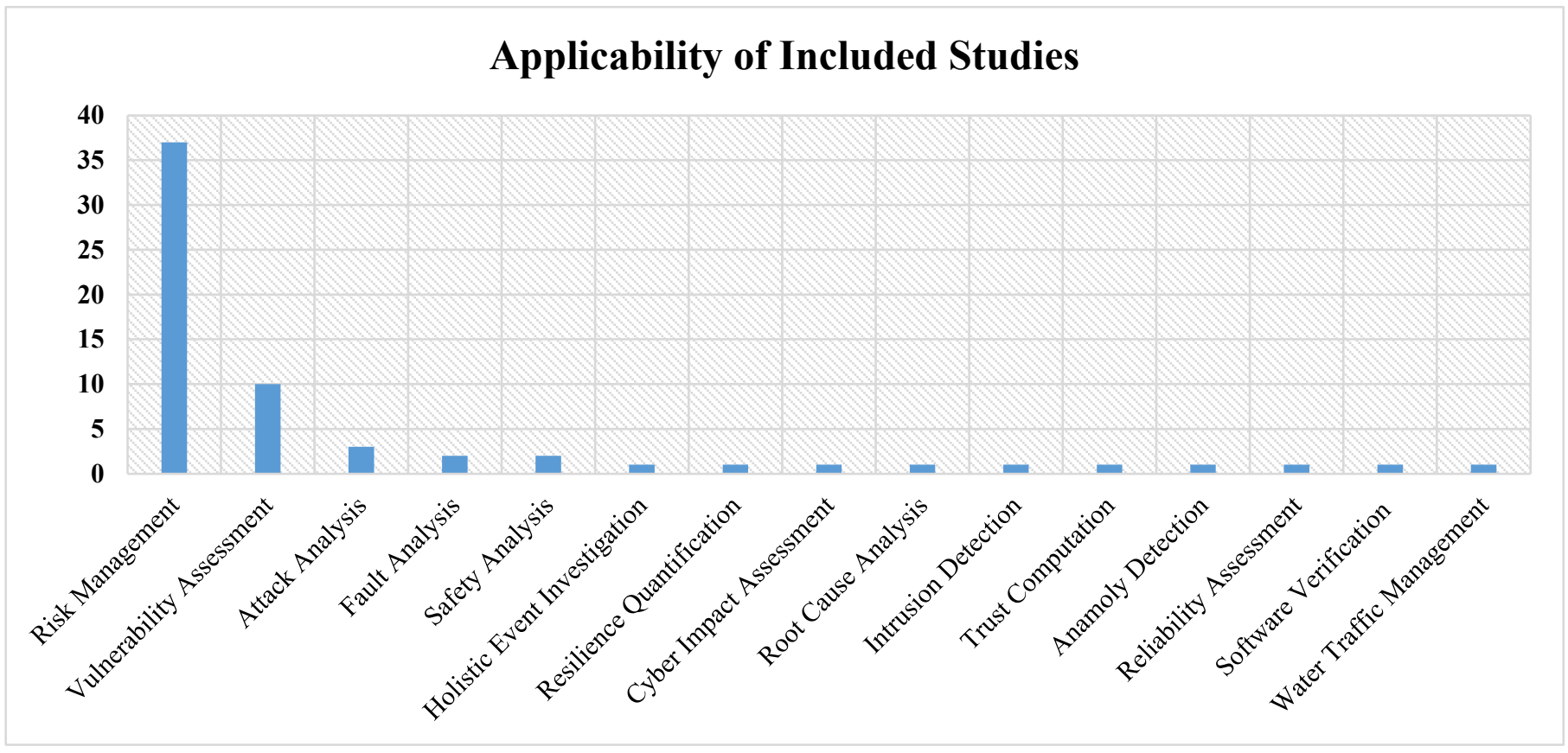

Figure 10. Applicability of included studies. 


\subsection{What Have Been the Targeted Application Domains?}

Figure 11 demonstrates the application sectors of BN and GT models for jointly monitoring safety and security events. The key sectors are the maritime $(14 \%)$, vehicle transportation (13\%), railway (13\%), nuclear $(6 \%)$, chemical $(6 \%)$, gas and pipelines $(5 \%)$, smart grid (5\%), network security (5\%), air transportation (3\%), public sector $(3 \%)$, and CPS (3\%) industries. The other preferred application sectors were software $(2 \%)$, water traffic system $(2 \%)$, ICS $(2 \%)$, education $(2 \%)$, UAV $(2 \%)$, complex systems $(2 \%)$, oil wharf handling $(2 \%)$, process plant $(2 \%)$, socio-technical systems $(2 \%)$, SoS $(2 \%)$, navigation environment $(2 \%)$, petroleum plants $(2 \%)$, mobile networks $(2 \%)$, cognitive radio networks $(2 \%)$, Asian games $(2 \%)$, and medical $(2 \%)$.

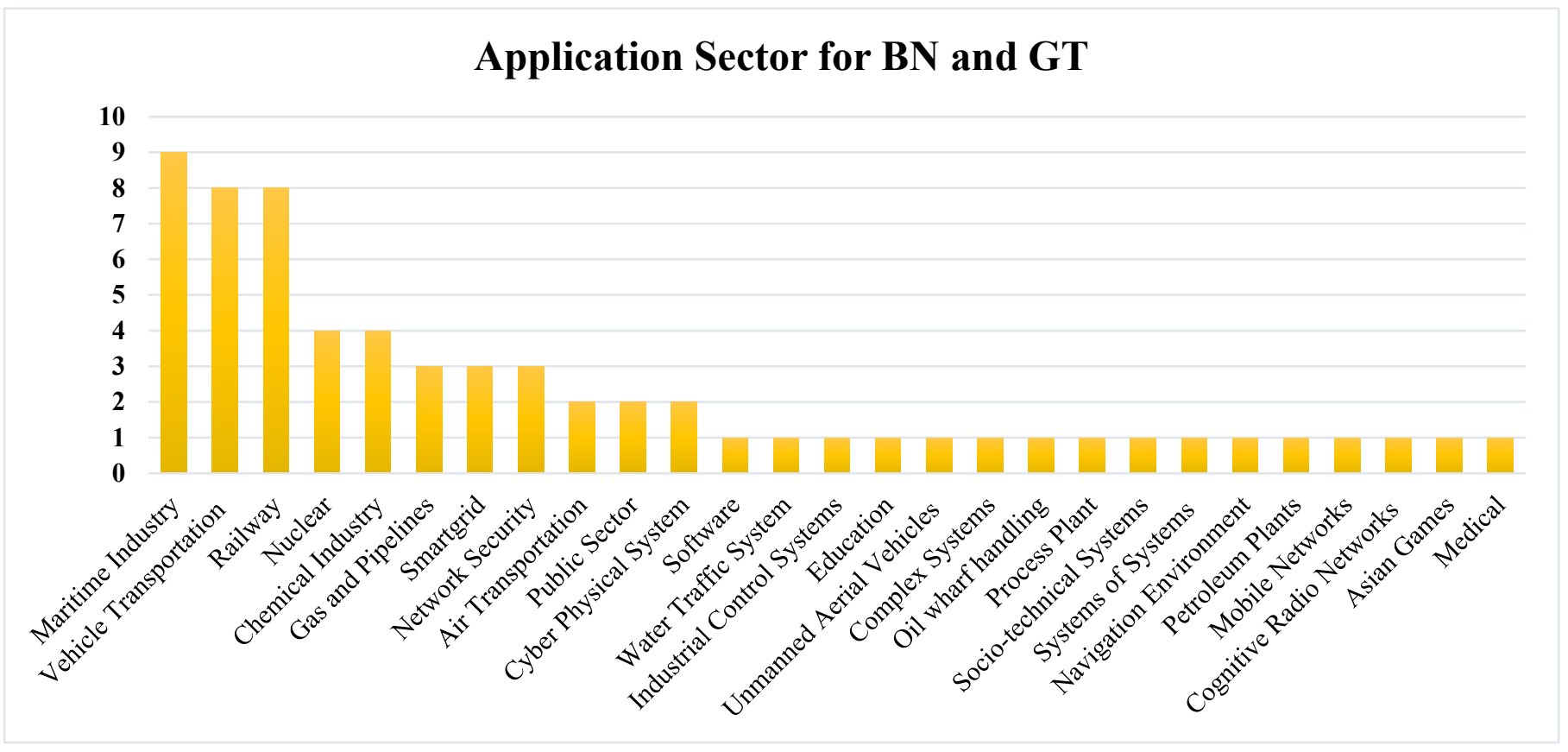

Figure 11. Application sectors of included studies.

\subsection{What Solutions Have Been Developed in the Identified Studies?}

This RQ aims to provide insight into the existing solutions, based on GT or BN, for integrating security and safety. The research outcomes of the included studies were shown in Table 5. It has been observed that $60 \%$ of the included studies have focused on risk assessment and monitoring. Meizhi et al. [44] presented a statistical evaluation of risks to achieve valuable insights into ports protection and build the fundamental BN approach. A dynamic model was introduced, using expert judgment and historical data to evaluate the emergency risk of sea lanes. André et al. [105] focused on protecting ventricular assist devices (VAD)-related risks that have great significance for patient safety, having customized VAD, regarding patients' intensity of sickness and metabolism. Moreover, safety-oriented guidelines are introduced, which also plays an indispensable role in decreasing risk reduction. 
Table 5. Research outcomes of included studies.

\begin{tabular}{|c|c|c|c|}
\hline Study & Research Outcome & Study & Research Outcome \\
\hline Xiaorong et al. [42] & Risk Assessment Model & Galizia et al. [74] & Risk Analysis Framework \\
\hline Lipeng et al. [43] & Systematic Causation Model & Francesca et al. [75] & $\begin{array}{l}\text { Vulnerability Assessment } \\
\text { Method }\end{array}$ \\
\hline Meizhi et al. [44] & $\begin{array}{c}\text { Dynamic Bayesian Network } \\
\text { Model }\end{array}$ & Zhao et al. [76] & Safety State Assessment Model \\
\hline Raditya et al. [45] & $\begin{array}{l}\text { Risk Oriented Decision-Making } \\
\text { Method }\end{array}$ & Mark et al. [77] & Vulnerability Assessment \\
\hline Tai-hua et al. [46] & Risk Assessment Model & Remya et al. [78] & System Safety Approach \\
\hline Mingjing et al. [47] & Interpretative Structural Model & Xin Chen [79] & Polynomial-Time Algorithm \\
\hline Xiaoxue et al. [48] & $\begin{array}{l}\text { An Integrated Security and } \\
\text { Safety Framework }\end{array}$ & Mark et al. [80] & $\begin{array}{c}\text { Extended Risk Evaluation } \\
\text { Model }\end{array}$ \\
\hline Xin et al. [49] & $\begin{array}{c}\text { Ideological Security Assessment } \\
\text { Method }\end{array}$ & Martin et al. [81] & Spatial Agent Enabled Model \\
\hline Meizhi et al. [50] & Analytical Model & Jinsoo et al. [82] & Security Risk Model \\
\hline Niamat et al. [51] & Resilience Framework & Marco et al. [83] & Transformational Approach \\
\hline Chengpeng et al. [52] & Risk Assessment Model & Matti et al. [84] & Risk Assessment Method \\
\hline Yi et al. [53] & $\begin{array}{c}\text { Risk Probability Evaluation } \\
\text { Model }\end{array}$ & Xiqiang et al. [85] & $\begin{array}{c}\text { BN-Based Structure Learning } \\
\text { Algorithm }\end{array}$ \\
\hline Barry et al. [54] & Cyber Risk Classification Model & Yongjia et al. [86] & Three-Layer Bayesian Model \\
\hline Alexandre et al. [55] & $\begin{array}{l}\text { Cyber Impact Evaluation } \\
\text { Framework }\end{array}$ & Kairan et al. [87] & Security Assessment Model \\
\hline Sabarathinam et al. [56] & $\begin{array}{c}\text { A Root Cause Evaluation } \\
\text { Framework }\end{array}$ & Amal et al. [88] & Offshore Piracy Solution \\
\hline Seyedmohsen et al. [57] & Decision-Making Tool & Guannan et al. [89] & $\begin{array}{c}\text { Dependability Evaluation } \\
\text { Model }\end{array}$ \\
\hline Mario et al. [58] & Intrusion Recognition System & Jiali et al. [90] & Fuzzy-Based BN Model \\
\hline Chao et al. [59] & $\begin{array}{l}\text { Vulnerability Assessment Graph } \\
\text { Model }\end{array}$ & Sher et al. [91] & Mobile Petri Net Model \\
\hline Nima et al. [60] & $\begin{array}{l}\text { Cost Robust Approach for } \\
\text { Domino Effects }\end{array}$ & LONG et al. [92] & Combined BN an FTA Model \\
\hline Hui et al. [61] & $\begin{array}{l}\text { Risk Interaction Analysis } \\
\text { Method }\end{array}$ & Zeng Xianfeng [93] & BN enabled Model \\
\hline Xiqiang et al. [62] & Risk Management Model & TIAN et al. [94] & Multi-layer System \\
\hline Jamal et al. [63] & $\begin{array}{l}\text { Model-Driven Assessment } \\
\text { Approach }\end{array}$ & William et al. [95] & Unified Framework \\
\hline Elvin et al. [64] & $\begin{array}{l}\text { Malicious Node Detection } \\
\text { Approach }\end{array}$ & Jinsoo et al. [96] & Security Risk Model \\
\hline Xiaoyan et al. [65] & Risk Identification Model & Stefan et al. [97] & Attack Detection Method \\
\hline Ying et al. [66] & Risk Analysis Method & Jingjing et al. [98] & Fault Diagnosis Method \\
\hline Subhojeet et al. [67] & $\begin{array}{l}\text { Graph-based Anomaly } \\
\text { Detection Technique }\end{array}$ & John et al. [99] & $\begin{array}{c}\text { Security Risk Assessment } \\
\text { Method }\end{array}$ \\
\hline Huai et al. [68] & GT-BNbased Method & Heung et al. [100] & Fault Estimation Method \\
\hline Gabriele et al. [69] & $\begin{array}{c}\text { A Probabilistic Risk Evaluation } \\
\text { Approach }\end{array}$ & Chaze et al. [101] & Risk Management System \\
\hline Zhiqiang et al. [70] & Risk Assessment Model & Mo Ming [102] & New GT Method \\
\hline
\end{tabular}


Table 5. Cont.

\begin{tabular}{cccc}
\hline Study & Research Outcome & Study & Research Outcome \\
\hline Jinsoo et al. [71] & A Cyber Security Risk Model & Shuliang et al. [103] & $\begin{array}{c}\text { Vulnerability Analysis } \\
\text { Framework }\end{array}$ \\
\hline Donya et al. [72] & $\begin{array}{c}\text { Security Vulnerability Valuation } \\
\text { Method }\end{array}$ & Song et al. [104] & BN-Enabled Model \\
\hline Xianyou et al. [73] & Network Security Model & André et al. [105] & Risk Mitigation Approach \\
\hline
\end{tabular}

\subsection{How Is Performance Validated for Developed Techniques and Algorithmic Solutions?}

Validation approaches are essential for BN or GT methods, in order to analyze the performance of developed methodologies. In this SLR, it is observed that 56 out of 64 studies were validated by different mechanisms, and the remaining 8 studies have not reported the validation process, as shown in Figure 12. Sensitivity analyses (20\% of included studies) perform a critical function in estimating the robustness of the outcomes on the principal analyses of the developed approaches. It is an important measure to evaluate the influence or impact of key hypotheses or variations on the specific infrastructure, including different analysis methods, protocol variations, outliers, definitions of results, and missing data, among others [48-52]. Another important aspect for validating the proposed technique is comparative analysis ( $20 \%$ of included studies), in which the outcomes of distinct models with different assumptions are compared with the developed approaches $[79,80]$. The other validation mechanisms recognized in the included studies were expert evaluation, scenarios development, statistical analysis, empirical analysis, reachability graph, diagnostic analysis, checklists, cross-validation, and minimax analysis, $16 \%, 12 \%, 8 \%, 3 \%, 2 \%, 2 \%, 2 \%$, $2 \%$, and $2 \%$, respectively.

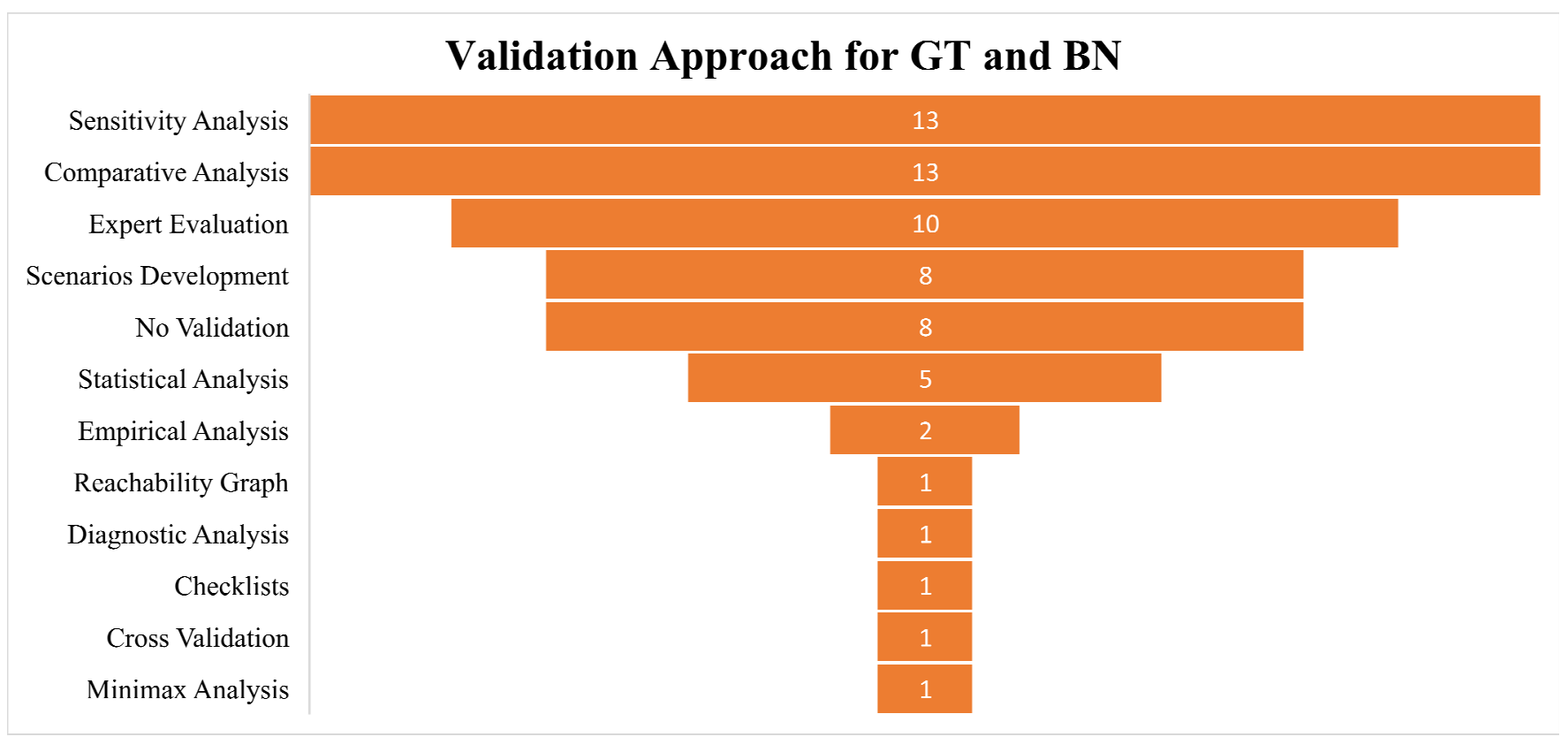

Figure 12. Validation approaches of included studies.

\subsection{What Are the Advantages and Disadvantages of Existing Studies?}

As elaborated in the included studies, the incorporation of safety and security measures based on GT and BN can benefit different CIs. Although there are certain shortcomings with the developed solutions, the advantages and disadvantages of existing BN or GT methods are discussed in this section, as shown in Table 6. 
Table 6. Pros and cons of included studies.

\begin{tabular}{|c|c|c|}
\hline Study & Pros & Cons \\
\hline Xiaorong et al. [42] & $\begin{array}{l}\text { Offers a feasible solution for risk assessment } \\
\text { in CPS, the feasibility is verified based on } \\
\text { two event scenarios. }\end{array}$ & $\begin{array}{l}\text { Lacks in presenting the finished model of } \\
\text { the research. }\end{array}$ \\
\hline Lipeng et al. [43] & $\begin{array}{l}\text { The key benefit of the proposed model is that } \\
\text { its applicability is checked in multiple } \\
\text { scenarios. }\end{array}$ & $\begin{array}{l}\text { The process consumes a lot of time, thus } \\
\text { restricting the model's application up to } \\
\text { few only. }\end{array}$ \\
\hline Meizhi et al. [44] & Utilization of vast dataset. & The use case areas are fixed. \\
\hline Raditya et al. [45] & $\begin{array}{c}\text { This study is useful in offering real-time risk } \\
\text { management options to mitigate cyber } \\
\text { threats. }\end{array}$ & $\begin{array}{l}\text { This study has not provided conclusive } \\
\text { data, as it was an early study. }\end{array}$ \\
\hline Tai-hua et al. [46] & $\begin{array}{l}\text { Potential to be applied for Chinese } \\
\text { enterprises in presenting efficient anomaly } \\
\text { prevention and response policies. }\end{array}$ & $\begin{array}{c}\text { It is specified for Chinese enterprises for } \\
\text { a Chinese problem. Readjustment is } \\
\text { needed if used in other places. }\end{array}$ \\
\hline Mingjing et al. [47] & $\begin{array}{l}\text { Efficient in enhancing security in urban } \\
\text { express logistics and avoiding safety hazards. }\end{array}$ & Merely a prototype is proposed. \\
\hline Xiaoxue et al. [48] & $\begin{array}{l}\text { The authors recommended low vulnerable } \\
\text { and improved resilient perspective for the } \\
\text { northern sea route. }\end{array}$ & Resilience level needs improvement. \\
\hline Xin et al. [49] & $\begin{array}{l}\text { Improves evaluation accuracy and reduces } \\
\text { estimation error for the educational sector. }\end{array}$ & $\begin{array}{l}\text { It has a limited use case to demonstrate } \\
\text { its developed method. }\end{array}$ \\
\hline Meizhi et al. [50] & $\begin{array}{l}\text { Various significant influencing factors for } \\
\text { maritime piracy are identified, and the } \\
\text { applicability is authenticated using } \\
\text { sensitivity analysis. }\end{array}$ & Feasibility issues, due to limited data. \\
\hline Niamat et al. [51] & $\begin{array}{l}\text { The capability of framework to be applied for } \\
\text { different sectors. }\end{array}$ & $\begin{array}{l}\text { This study does not offer } \\
\text { decision-theoretic troubleshooting. } \\
\text { Moreover, the framework is still } \\
\text { preliminary. }\end{array}$ \\
\hline Chengpeng et al. [52] & $\begin{array}{l}\text { Offers efficient and flexible risk management } \\
\text { for real circumstances. }\end{array}$ & $\begin{array}{l}\text { It is limited up to only operational } \\
\text { aspects. In contrast, complete analysis is } \\
\text { not focused on this tool. }\end{array}$ \\
\hline Yi et al. [53] & $\begin{array}{l}\text { More accuracy in the navigation risk of ships } \\
\text { in the bridge area in distinct conditions. }\end{array}$ & $\begin{array}{l}\text { This research is validated based on a } \\
\text { specific use case. }\end{array}$ \\
\hline Barry et al. [54] & $\begin{array}{l}\text { High prediction accuracy (nearly } 100 \% \text { ) of } \\
\text { the qualitative and quantitative risk factors. }\end{array}$ & It is used for specific sectors only. \\
\hline Alexandre et al. [55] & $\begin{array}{l}\text { Efficient in demonstrating cyber impacts in } \\
\text { whole systems based on invaders and } \\
\text { defenders' plans, without knowing the } \\
\text { hard-to-assess attacker's activities. }\end{array}$ & Limited scenarios and tested situations. \\
\hline Sabarathinam et al. [56] & $\begin{array}{l}\text { To assist in determining the root cause of } \\
\text { risks within the systems. }\end{array}$ & The results are based on simulations. \\
\hline Seyedmohsen et al. [57] & $\begin{array}{c}\text { Both qualitative and quantitative factors are } \\
\text { used with rigorous testing. }\end{array}$ & $\begin{array}{l}\text { Perhaps overspecialized. Only to be used } \\
\text { in its sector. }\end{array}$ \\
\hline Mario et al. [58] & $\begin{array}{l}\text { The accuracy of the developed model is } \\
\text { reasonably optimal. }\end{array}$ & $\begin{array}{l}\text { Lacking in measuring efficiency in } \\
\text { real-time scenarios. }\end{array}$ \\
\hline Chao et al. [59] & $\begin{array}{l}\text { Ability to decrease the risk of intended } \\
\text { attacks by continuous monitoring }\end{array}$ & Allocation optimization is not considered. \\
\hline
\end{tabular}


Table 6. Cont

\begin{tabular}{|c|c|c|}
\hline Study & Pros & Cons \\
\hline Nima et al. [60] & $\begin{array}{l}\text { A cost-efficient solution for vulnerability } \\
\text { assessment. }\end{array}$ & Limited to restricted sectors. \\
\hline Hui et al. [61] & $\begin{array}{l}\text { Offers practical recommendations for } \\
\text { establishing countermeasures in diminishing } \\
\text { risk events in railway. }\end{array}$ & $\begin{array}{l}\text { A risk mitigation strategy is not } \\
\text { presented. }\end{array}$ \\
\hline Xiqiang et al. [62] & $\begin{array}{l}\text { Efficient in diagnosing of main factors, which } \\
\text { may put threats to rail transport. }\end{array}$ & Threat actors are not specified. \\
\hline Jamal et al. [63] & $\begin{array}{l}\text { High efficiency in autonomous quarry } \\
\text { mitigation associated with signal } \\
\text { interference. }\end{array}$ & $\begin{array}{l}\text { Cannot protect from all high impact } \\
\text { attacks. }\end{array}$ \\
\hline Elvin et al. [64] & $\begin{array}{l}\text { Improved malicious detection in vehicular } \\
\text { networks, due to inclusion of perception and } \\
\text { reasoning in the decision building process. }\end{array}$ & Results are still preliminary. \\
\hline Xiaoyan et al. [65] & $\begin{array}{c}\text { Continuous evaluation of possible incident } \\
\text { frequencies and outcomes by providing } \\
\text { unique risk awareness. }\end{array}$ & $\begin{array}{l}\text { Conditional probability tables are not } \\
\text { presented. }\end{array}$ \\
\hline Ying et al. [66] & $\begin{array}{l}\text { The casual diagnostic analysis in complex } \\
\text { and uncertain environments. More accurate } \\
\text { than fault tree analysis. }\end{array}$ & $\begin{array}{l}\text { Complex data collection process, an } \\
\text { automatic technology for collecting } \\
\text { required information, is not considered. }\end{array}$ \\
\hline Subhojeet et al. [67] & $\begin{array}{l}\text { Capability to recognize malicious threats and } \\
\text { differentiate them from safety-critical } \\
\text { activities. }\end{array}$ & The developed model is still preliminary. \\
\hline Huai et al. [68] & $\begin{array}{l}\text { Failure analysis from different prospects, } \\
\text { such as topology, functional restriction, } \\
\text { environmental, and dynamic. }\end{array}$ & $\begin{array}{l}\text { There needs an improvement for } \\
\text { analyzing network measurements and } \\
\text { results of unit failures. }\end{array}$ \\
\hline Gabriele et al. [69] & $\begin{array}{l}\text { Accurate quantitative estimation of attack } \\
\text { success probability and for the classification } \\
\text { of the more hazardous escalation situations. }\end{array}$ & $\begin{array}{l}\text { Lacks in performing a quantitative } \\
\text { evaluation of the credibility of attack } \\
\text { success. }\end{array}$ \\
\hline Zhiqiang et al. [70] & $\begin{array}{l}\text { An efficient quantitative risk assessment for } \\
\text { finding security weaknesses. }\end{array}$ & $\begin{array}{l}\text { The results need to be verified based on } \\
\text { real-time scenarios. }\end{array}$ \\
\hline Jinsoo et al. [71] & $\begin{array}{l}\text { A generic approach toward monitoring and } \\
\text { mitigating security and safety risks. }\end{array}$ & $\begin{array}{l}\text { This study is conducted for a specific } \\
\text { sector. }\end{array}$ \\
\hline Donya et al. [72] & $\begin{array}{l}\text { This study efficiently resolves uncertainties } \\
\text { in the failure probability of elements and the } \\
\text { temporal classification of occurrences. }\end{array}$ & The developed model is still preliminary. \\
\hline Xianyou et al. [73] & $\begin{array}{l}\text { Using multiple BN models to accurately } \\
\text { assess vulnerabilities. }\end{array}$ & The developed model is still preliminary. \\
\hline Galizia et al. [74] & $\begin{array}{l}\text { New recommendations for resilience in } \\
\text { socio-technical systems. }\end{array}$ & Lacks in presenting real-time analysis. \\
\hline Francesca et al. [75] & $\begin{array}{l}\text { A systematic procedure for vulnerability } \\
\text { assessment against outside threats. }\end{array}$ & $\begin{array}{l}\text { Insider threats are not considered in this } \\
\text { study. }\end{array}$ \\
\hline Zhao et al. [76] & $\begin{array}{c}\text { An experiential analysis that effectively } \\
\text { exhibits the safety status for the navigation } \\
\text { environment. }\end{array}$ & Threats are not specified. \\
\hline Mark et al. [77] & $\begin{array}{l}\text { Increase awareness in vulnerability } \\
\text { management for the chemical industry. }\end{array}$ & $\begin{array}{l}\text { This study is conducted for a specific } \\
\text { sector. }\end{array}$ \\
\hline Remya et al. [78] & $\begin{array}{l}\text { Robustly monitoring of unmodeled and } \\
\text { unexpected failures. }\end{array}$ & $\begin{array}{l}\text { This study does not robustly manage } \\
\text { unexpected and unmodeled failures. }\end{array}$ \\
\hline Xin Chen [79] & $\begin{array}{l}\text { Efficiently evaluate vulnerabilities and } \\
\text { crucial devices of the system. }\end{array}$ & $\begin{array}{l}\text { The simulation results still need to be } \\
\text { modified. }\end{array}$ \\
\hline
\end{tabular}


Table 6. Cont

\begin{tabular}{|c|c|c|}
\hline Study & Pros & Cons \\
\hline Mark et al. [80] & $\begin{array}{c}\text { Efforts in delivering awareness to society for } \\
\text { the development of databases about } \\
\text { associated security failures. }\end{array}$ & $\begin{array}{l}\text { The developed methodology is still } \\
\text { preliminary. }\end{array}$ \\
\hline Martin et al. [81] & $\begin{array}{c}\text { The accuracy of the developed model is } \\
\text { reasonably well in comparing existing } \\
\text { approaches. }\end{array}$ & The developed model is still preliminary. \\
\hline Jinsoo et al. [82] & $\begin{array}{l}\text { An efficient mitigation measures for real-time } \\
\text { analysis of risks in the nuclear sector. }\end{array}$ & $\begin{array}{l}\text { The proposed research affects BN } \\
\text { accuracy. }\end{array}$ \\
\hline Marco et al. [83] & $\begin{array}{l}\text { Results verified for combined attacks with } \\
\text { mutual and non-trivial influences. }\end{array}$ & Limited to only one case study. \\
\hline Matti et al. [84] & $\begin{array}{l}\text { This research is helpful in documenting the } \\
\text { expert knowledge. }\end{array}$ & $\begin{array}{l}\text { Real-time traffic monitoring control has } \\
\text { not been performed. }\end{array}$ \\
\hline Xiqiang et al. [85] & $\begin{array}{l}\text { Applicability in emergency cases with high } \\
\text { accuracy. }\end{array}$ & $\begin{array}{l}\text { Specific for the case study. Challenging } \\
\text { implementing in other fields. }\end{array}$ \\
\hline Yongjia et al. [86] & Having low-SNR and better availability. & $\begin{array}{l}\text { The results are only preliminary. Testing } \\
\text { on the different scenarios is needed. }\end{array}$ \\
\hline Kairan et al. [87] & $\begin{array}{l}\text { A security assessment is verified using a use } \\
\text { case study. }\end{array}$ & The results are only preliminary. \\
\hline Amal et al. [88] & $\begin{array}{l}\text { BN implementation improves the Sargos } \\
\text { system with is inherent abilities. }\end{array}$ & $\begin{array}{l}\text { A specific approach is developed for the } \\
\text { maritime industry; a lot of modifications } \\
\text { are needed for use in other sectors. }\end{array}$ \\
\hline Guannan et al. [89] & $\begin{array}{l}\text { A dynamic and optimal risk assessment for } \\
\text { the software industry. }\end{array}$ & $\begin{array}{l}\text { The simulation results still need to be } \\
\text { modified. }\end{array}$ \\
\hline Jiali et al. [90] & $\begin{array}{l}\text { Increases accuracy for risk assessment in the } \\
\text { maritime industry. }\end{array}$ & $\begin{array}{l}\text { Lacks in empirical data for circumstantial } \\
\text { results. }\end{array}$ \\
\hline Sher et al. [91] & $\begin{array}{l}\text { Offers support mobility, protection, and } \\
\text { concurrency for software verification. }\end{array}$ & Threat actors are not specified. \\
\hline LONG et al. [92] & $\begin{array}{l}\text { Offer recommendations for the designing } \\
\text { and implementing of the energy sector to } \\
\text { decrease the potential risks. }\end{array}$ & $\begin{array}{l}\text { Specific use cases are hard to emulate } \\
\text { outside of the sector or system. }\end{array}$ \\
\hline Zeng Xianfeng [93] & $\begin{array}{l}\text { Presented reliable dataset for research } \\
\text { purposes in the railway sector. }\end{array}$ & Lack of practicality in railways. \\
\hline TIAN et al. [94] & $\begin{array}{l}\text { More robust solution for the water traffic } \\
\text { system. }\end{array}$ & $\begin{array}{l}\text { The human factor is not considered in } \\
\text { real-time monitoring and is lacking for } \\
\text { managing adequate personnel. }\end{array}$ \\
\hline William et al. [95] & $\begin{array}{l}\text { Applicable for both known and unknown } \\
\text { vulnerabilities. }\end{array}$ & Limited applicability domains. \\
\hline Jinsoo et al. [96] & $\begin{array}{l}\text { This study assists in identifying fundamental } \\
\text { factors that may pose cybersecurity hazards. }\end{array}$ & $\begin{array}{l}\text { The simulation results still need to be } \\
\text { modified. }\end{array}$ \\
\hline Stefan et al. [97] & $\begin{array}{l}\text { Reduces communication redundancies and } \\
\text { enables data uniformity inspection in } \\
\text { transportation. }\end{array}$ & Limited usability. \\
\hline Jingjing et al. [98] & $\begin{array}{l}\text { Improved accuracy and effective use of train } \\
\text { control system. }\end{array}$ & $\begin{array}{l}\text { Merely a preliminary analysis for the } \\
\text { high-speed railway. }\end{array}$ \\
\hline John et al. [99] & $\begin{array}{c}\text { Feasibility and compatibility for protecting } \\
\text { air transportation. }\end{array}$ & The results are only preliminary. \\
\hline Heung et al. [100] & $\begin{array}{l}\text { Systematic evaluation of the anticipated } \\
\text { faults in the system. }\end{array}$ & $\begin{array}{l}\text { There is not sufficient data of } \\
\text { safety-critical software, assembled for } \\
\text { real-time systems. }\end{array}$ \\
\hline
\end{tabular}


Table 6. Cont.

\begin{tabular}{ccc}
\hline Study & Pros & Cons \\
\hline Chaze et al. [101] & $\begin{array}{c}\text { To efficiently recognize and respond to risks } \\
\text { in maritime piracy. }\end{array}$ & $\begin{array}{c}\text { There is a need for an ontology for proper } \\
\text { usability. }\end{array}$ \\
Mo Ming [102] & $\begin{array}{c}\text { Correctly demonstrate the network safety } \\
\text { situation and improve the safety of the } \\
\text { system. }\end{array}$ & $\begin{array}{c}\text { Heavily integrated with its system; } \\
\text { therefore, difficult to use outside of } \\
\text { network security analysis. }\end{array}$ \\
\hline Shuliang et al. [103] & $\begin{array}{c}\text { Efficiency in analyzing vulnerabilities in } \\
\text { smart grid. }\end{array}$ & $\begin{array}{c}\text { The developed model is more } \\
\text { methodological than practical. }\end{array}$ \\
\hline Song et al. [104] & $\begin{array}{c}\text { The developed BN model plays a significant } \\
\text { role in reducing fire risks. }\end{array}$ & $\begin{array}{c}\text { The testing is not entirely performed } \\
\text { before winter games. }\end{array}$ \\
\hline André et al. [105] & $\begin{array}{c}\text { Providing a better quality of life and more } \\
\text { prolonged survival of patients. }\end{array}$ & The threat actors are not specified. \\
\hline
\end{tabular}

\subsection{Limitations}

This study has given below limitations:

(1) The inclusion of articles is solely based on the English language, which indicates that notable studies of security and safety integration based on BN or GT in other languages have not been considered.

(2) The results of this SLR are based on a restricted number of databases. These databases are used, due to the widespread usage for querying papers in the field of GT and BN.

(3) Included studies were performed in different applications, so it might be not possible to compare each perspective.

\section{Conclusions}

Modern systems must simultaneously guarantee security and safety to provide continuous and accurate execution of crucial roles and services. Since security and safety depend on each other, they must be collectively applied to acquire the root cause assessment of noticeable issues. Therefore, numerous methods are developed to integrate security and safety; however, BN and GT are considered in this SLR, due to their extensive usage in various applications. This SLR includes 64 studies, and given below are concluding points:

(a) It is observed that from the 64 included studies, 51 used BN models, 10 utilized GT models, and the remaining 3 were based on united BN and GT.

(b) Most development scenarios utilized 40 nodes for performing experiments to observe unintentional failures or risks for GT and BN models.

(c) It has been emphasized that approximately one-third of BN and GT models were evaluated in real-time; however, others were either based on simulation analysis or theoretical concepts.

(d) There were two types of data sources (EK and ED) used for developing BN and GT models for different applications.

(e) The key performance validation mechanisms for the included studies were statistical analysis, expert evaluation, and sensitivity analysis.

The future research directions for safety and security integration were the following:

(a) There is a need to develop a generic tool or method or standard to combine security and safety, which can be helpful for different applications, since the significance of integrating both measures was demonstrated in this SLR, and a generic approach may offer feasibility and flexibility.

(b) It is observed that there are various validation methods for evaluating BN or GT. A more extended investigation is necessary to estimate the accuracy and efficiency of validation mechanisms, in order to find the optimal option. 
(c) Moreover, there is a need to research to acquire information about the suitable number of nodes to ensure reliable and accurate performance for ensuring safety and security based on BN or GT models.

(d) Further research could improve Bayesian analysis based on the Metropolis-Hastings algorithm and Gaussian distributions [107].

Author Contributions: S.P., V.G. and S.K. designed the study theme and conducted the literature study. S.P. and V.G. examined the data from different databases and performed initial data screening. S.P. interpreted the results and wrote the paper. V.G. and S.K. analyzed data, verified the results, and revised the paper. S.K. assisted in supervising the activities and study's well-organized procedure. All authors have read and agreed to the published version of the manuscript.

Funding: This research received funding from the Research Council of Norway through (a) the CybWin (Cybersecurity Platform for Assessment and Training for Critical Infrastructures-Legacy to digital twin), project no. 287808; and (b) the SFI Norwegian Centre for Cybersecurity in Critical Sectors (NORCICS), project no. 310105.

Institutional Review Board Statement: Not applicable.

Informed Consent Statement: Not applicable.

Data Availability Statement: Not applicable.

Acknowledgments: This work has received funding from the Research Council of Norway through (a) the CybWin (Cybersecurity Platform for Assessment and Training for Critical InfrastructuresLegacy to digital twin), project no. 287808; and (b) the SFI Norwegian Centre for Cybersecurity in Critical Sectors (NORCICS), project no. 310105. Also, authors would like to express great appreciation to IIK Department at NTNU Gjovik Campus, and ICT Research Department at NR.

Conflicts of Interest: The authors declare no conflict of interest.

\section{References}

1. Baker, T.; Asim, M.; MacDermott, Á.; Iqbal, F.; Kamoun, F.; Shah, B.; Alfandi, O.; Hammoudeh, M. A secure fog-based platform for SCADA-based IoT critical infrastructure. Softw. Pract. Exp. 2020, 50, 503-518. [CrossRef]

2. Kotenko, I.; Saenko, I.; Kushnerevich, A.; Branitskiy, A. Attack detection in IoT critical infrastructures: A machine learning and big data processing approach. In Proceedings of the 27th Euromicro International Conference on Parallel, Distributed and Network-Based Processing (PDP), Pavia, Italy, 13-15 February 2019; pp. 340-347.

3. Stellios, I.; Kotzanikolaou, P.; Psarakis, M.; Alcaraz, C.; Lopez, J. A survey of iot-enabled cyberattacks: Assessing attack paths to critical infrastructures and services. IEEE Commun. Surv. Tutor. 2018, 20, 3453-3495. [CrossRef]

4. Kornecki, A.J.; Liu, M. Fault Tree Analysis for Safety/Security Verification in Aviation Software. Electronics 2013, 2, 41-56. [CrossRef]

5. Schmittner, C.; Ma, Z.; Schoitsch, E.; Gruber, T. A case study of fmvea and chassis as safety and security co-analysis method for automotive cyber-physical systems. In Proceedings of the 1st ACM Workshop on Cyber-Physical System Security, Singapore, 14 April 2015; pp. 69-80.

6. Banerjee, A.; Venkatasubramanian, K.K.; Mukherjee, T.; Gupta, S.K.S. Ensuring safety, security, and sustainability of missioncritical cyber-physical systems. Proc. IEEE 2012, 100, 283-299. [CrossRef]

7. Kornecki, A.J.; Subramanian, N.; Zalewski, J. Studying interrelationships of safety and security for software assurance in cyberphysical systems: Approach based on bayesian belief networks. In Proceedings of the 2013 Federated Conference on Computer Science and Information Systems, Krakow, Poland, 8-11 September 2013; pp. 1393-1399.

8. John, A.; Yang, Z.; Riahi, R.; Wang, J. A risk assessment approach to improve the resilience of a seaport system using Bayesian networks. Ocean Eng. 2016, 111, 136-147. [CrossRef]

9. Zeng, J.; Wu, S.; Chen, Y.; Zeng, R.; Wu, C. Survey of attack graph analysis methods from the perspective of data and knowledge processing. Secur. Commun. Netw. 2019, 2019, 1-17. [CrossRef]

10. Sharma, R.; Kamble, S.S.; Gunasekaran, A.; Kumar, V.; Kumar, A. A systematic literature review on machine learning applications for sustainable agriculture supply chain performance. Comput. Oper. Res. 2020, 119, 104926. [CrossRef]

11. Gupta, R.; Tanwar, S.; Kumar, N.; Tyagi, S. Blockchain-based security attack resilience schemes for autonomous vehicles in industry 4.0: A systematic review. Comput. Electr. Eng. 2020, 86, 106717. [CrossRef]

12. Chockalingam, S.; Hadžiosmanović, D.; Pieters, W.; Teixeira, A.A.; van Gelder, P. Integrated Safety and Security Risk Assessment Methods: A Survey of Key Characteristics and Applications. In Critical Information Infrastructures Security; Havarneanu, G., Setola, R., Nassopoulos, H., Wolthusen, S., Eds.; Lecture Notes in Computer Science; Springer: Cham, Switzerland, 2017 ; Volume 10242. [CrossRef] 
13. Lallie, H.S.; Debattista, K.; Bal, J. A review of attack graph and attack tree visual syntax in cyber security. Comput. Sci. Rev. 2020, 35, 100219. [CrossRef]

14. Fovino, L.N.; Masera, M.; De Cian, A. Integrating cyber attacks within fault trees. Reliab. Eng. Syst. Saf. 2009, 94-99, 1394-1402. [CrossRef]

15. Kriaa, S.; Bouissou, M. Modeling safety and security interdependencies with bdmp (boolean logic driven markov processes). In SAFECOMP 2014; Bondavalli, A., Ceccarelli, A., Ortmeier, F., Eds.; Springer: Cham, Switzerland, 2014.

16. Abdo, H.; Kaouk, M.; Flaus, J.-M.; Masse, F. A safety/security risk analysis approach of Industrial Control Systems: A cyber bowtie-Combining new version of attack tree with bowtie analysis. Comput. Secur. 2018, 72, 175-195. [CrossRef]

17. Galagedarage Don, M.; Khan, F. Process Fault Prognosis Using Hidden Markov Model—Bayesian Networks Hybrid Model. Ind. Eng. Chem. Res. 2019, 58, 12041-12053. [CrossRef]

18. Cooper, G.F.; Herskovits, E. A Bayesian method for the induction of probabilistic networks from data. Mach. Learn. 1992, 9, 309-347. [CrossRef]

19. Afenyo, M.; Khan, F.; Veitch, B.; Yang, M. Arctic shipping accident scenario analysis using Bayesian Network approach. Ocean Eng. 2017, 133, 224-230. [CrossRef]

20. Kabir, S.; Papadopoulos, Y. Applications of Bayesian networks and Petri nets in safety, reliability, and risk assessments: A review. Saf. Sci. 2019, 115, 154-175. [CrossRef]

21. Bruni, R.; Melgratti, H.; Montanari, U. Bayesian network semantics for Petri nets. Theor. Comput. Sci. 2020, 807, 95-113. [CrossRef]

22. Lichte, D.; Wolf, K.-D. Bayesian Network Based Analysis of Cyber Security Impact on Safety. In Proceedings of the 29th European Safety and Reliability Conference, Hannover, Germany, 22-26 September 2019; pp. 1502-1509.

23. Jensen, F.V.; Nielsen, T.D. Bayesian Networks and Decision Graphs; Springer: Berlin, Germany, 2007.

24. Heckerman, D.; Geiger, D.; Chickering, D.M. Learning bayesian networks: The combination of knowledge and statistical data. Mach. Learn. 1995, 20, 197-243. [CrossRef]

25. Liao, W.; Ji, Q. Learning Bayesian network parameters under incomplete data with domain knowledge. Pattern Recognit. 2009, 42, 3046-3056. [CrossRef]

26. Friedman, N. The bayesian structural em algorithm. In Proceedings of the Fourteenth Conference on Uncertainty in Artificial Intelligence, Madison, WI, USA, 24-26 July 1998; pp. 129-138.

27. Blei, D.M.; Kucukelbir, A.; McAuliffe, J.D. Variational inference: A review for statisticians. J. Am. Stat. Assoc. 2017, 112, 859-877. [CrossRef]

28. Pelikan, M.; Goldberg, D.E.; Lobo, F.G. A survey of optimization by building and using probabilistic models. Comput. Optim. Appl. 2002, 21, 5-20. [CrossRef]

29. Khakzad, N.; Reniers, G. Using graph theory to analyze the vulnerability of process plants in the context of cascading effects. Reliab. Eng. Syst. Saf. 2015, 143, 63-73. [CrossRef]

30. Ferrario, E.; Pedroni, N.; Zio, E. Evaluation of the robustness of critical infrastructures by Hierarchical Graph representation, clustering and Monte Carlo simulation. Reliab. Eng. Syst. Saf. 2016, 155, 78-96. [CrossRef]

31. Leitold, D.; Vathy-Fogarassy, A.; Abonyi, J. Controllability and observability in complex networks-The effect of connection types. Sci. Rep. 2017, 7, 151. [CrossRef]

32. Dwivedi, A.; Yu, X. A Maximum-Flow-Based Complex Network Approach for Power System Vulnerability Analysis. IEEE Trans. Ind. Inform. 2011, 9, 81-88. [CrossRef]

33. Kabir, M.; Mishra, Y.; Bansal, R. Probabilistic load flow for distribution systems with uncertain PV generation. Appl. Energy 2016, 163, 343-351. [CrossRef]

34. Fu, X.; Sun, H.; Guo, Q.; Pan, Z.; Zhang, X.; Zeng, S. Probabilistic power flow analysis considering the dependence between power and heat. Appl. Energy 2017, 191, 582-592. [CrossRef]

35. Johansson, J.; Hassel, H. An approach for modelling interdependent infrastructures in the context of vulnerability analysis. Reliab. Eng. Syst. Saf. 2010, 95, 1335-1344. [CrossRef]

36. Casoetto, B.; Flottes, E.; Ardeois, J.; Thanh, N.; Joliot, J.-B.; Nait-Abdallah, R. How to commercialize reliable capacities on a com-plex transmission network? J. Nat. Gas. Sci. Eng. 2011, 3, 657-663. [CrossRef]

37. Chung, F.R.K.; Lu, L. Complex Graphs and Networks, Volume 107 of CBMS Regional Conference Series in Mathematics; American Mathematical Society: Providence, RI, USA, 2006.

38. Ahmat, K. Graph Theory and Optimization Problems for Very Large Networks; City University of New York: New York, NY, USA, 2009.

39. Shirinivas, S.G.; Vetrivel, S.; Elango, N.M. Applications of graph theory in computer science-An overview. Int. J. Eng. Sci. Technol. 2010, 2, 4610-4621.

40. Hossain, N.U.I.; Nur, F.; Hosseini, S.; Jaradat, R.; Marufuzzaman, M.; Puryear, S.M. A Bayesian network based approach for modeling and assessing resilience: A case study of a full service deep water port. Reliab. Eng. Syst. Saf. 2019, 189, 378-396. [CrossRef]

41. Silva, A.; Silva, K.; Rocha, A.; Queiroz, F. Calculating the trust of providers through the construction weighted Sec-SLA. Futur. Gener. Comput. Syst. 2019, 97, 873-886. [CrossRef]

42. Lyu, X.; Ding, Y.; Yang, S.-H. Bayesian Network Based C2P Risk Assessment for Cyber-Physical Systems. IEEE Access 2020, 8 , 88506-88517. [CrossRef] 
43. Fu, L.; Wang, X.; Liu, B.; Li, L. Investigation into the role of human and organizational factors in security work against terrorism at large-scale events. Saf. Sci. 2020, 128, 104764. [CrossRef]

44. Jiang, M.; Lu, J. Maritime accident risk estimation for sea lanes based on a dynamic Bayesian network. Marit. Policy Manag. 2020, 47, 649-664. [CrossRef]

45. Arief, R.; Khakzad, N.; Pieters, W. Mitigating cyberattack related domino effects in process plants via ICS seg-mentation. J. Inf. Secur. Appl. 2020, 51, 102450.

46. Yang, T.-H.; Qin, J.; Li, Z.-X. Public Safety Risk Assessment of Power Investment Project Based on Fuzzy Set and DS Evidence Theory. E3S Web Conf. 2020, 143, 02009. [CrossRef]

47. Zhao, M.; Ji, S.; Zhao, Q.; Chen, C.; Wei, Z.-L. Risk Influencing Factor Analysis of Urban Express Logistics for Public Safety: A Chinese Perspective. Math. Probl. Eng. 2020, 2020, 1-14. [CrossRef]

48. Ma, X.; Zhou, Q.; Liu, T.; Liu, Y.; Qiao, W. Security of the Arctic route from the resilience perspective: The ideal state, influencing factors, and evaluation. Marit. Policy Manag. 2020, 1-14. [CrossRef]

49. Gao, X. Study on Ideological Safety Assessment Methods for College Students in the New Era. In Proceedings of the 12th International Conference on Measuring Technology and Mechatronics Automation (ICMTMA), Phuket, Thailand, 28-29 February 2020; pp. 962-966.

50. Jiang, M.; Lu, J. The analysis of maritime piracy occurred in Southeast Asia by using Bayesian network. Transp. Res. Part E Logist. Transp. Rev. 2020, 139, 101965. [CrossRef]

51. Hossain, N.U.I.; Raed, J.; Seyedmohsen, H.; Mohammad, M.; Randy, K.B. A framework for modeling and assessing system resilience using a Bayesian network: A case study of an interdependent electrical infrastructure system. Int. J. Crit. Infrastruct. Prot. 2019, 25, 62-83. [CrossRef]

52. Hosseini, S.; Ivanov, D. Bayesian networks for supply chain risk, resilience and ripple effect analysis: A literature review. Expert Syst. Appl. 2020, 161, 113649. [CrossRef] [PubMed]

53. Wan, Y.; Liu, C.; Qiao, W. An advanced fuzzy Bayesian-based FMEA approach for assessing maritime supply chain risks. Transp. Res. Part E Logist. Transp. Rev. 2019, 125, 222-240. [CrossRef]

54. Sheehan, B.; Finbarr, M.; Martin, M.; Cian, R. Connected and autonomous vehicles: A cyber-risk classification framework. Transp. Res. Part A Policy Pract. 2019, 124, 523-536. [CrossRef]

55. Barreto, A.B.; Costa, P. Cyber-ARGUS-A mission assurance framework. J. Netw. Comput. Appl. 2019, 133, 86-108. [CrossRef]

56. Chockalingam, S.; Katta, V. Developing a Bayesian Network Framework for Root Cause Analysis of Observable Problems in Cyber-Physical Systems. In Proceedings of the 2019 IEEE Conference on Information and Communication Technology, Baku, Azerbaijan, 23-25 October 2019; pp. 1-6.

57. Hosseini, S. Sarder Development of a Bayesian network model for optimal site selection of electric vehicle charging station. Int. J. Electr. Power Energy Syst. 2018, 105, 110-122. [CrossRef]

58. Casillo, M.; Simone, C.; De Santo, M.; Pascale, F.; Santonicola, E. Embedded Intrusion Detection System for Detecting Attacks over CAN-BUS. In Proceedings of the 4th International Conference on System Reliability and Safety (ICSRS), Rome, Italy, 20-22 November 2019; pp. 136-141.

59. Chen, C.; Reniers, G.; Khakzad, N. Integrating safety and security resources to protect chemical industrial parks from man-made domino effects: A dynamic graph approach. Reliab. Eng. Syst. Saf. 2019, 191, 106470. [CrossRef]

60. Khakzad, N.; Reniers, G. Low-capacity utilization of process plants: A cost-robust approach to tackle man-made domino effects. Reliab. Eng. Syst. Saf. 2019, 191, 106114. [CrossRef]

61. Xu, H.; Zhang, Y.; Li, H.; Skitmore, M.; Yang, J.; Yu, F. Safety risks in rail stations: An interactive approach. J. Rail Transp. Plan. Manag. 2019, 11, 100148. [CrossRef]

62. Zhou, X. Security Analysis about Switching Equipment Based on Bayesian Networks. In Proceedings of the Sixth International Conference on Transportation Engineering, Chengdu, China, 20-22 September 2019; pp. 385-391.

63. El Hachem, J.; Sedaghatbaf, A.; Lisova, E.; Causevic, A. Using Bayesian Networks for a Cyberattacks Propagation Analysis in Systems-of-Systems. In Proceedings of the 26th Asia-Pacific Software Engineering Conference (APSEC), Putrajaya, Malaysia, 2-5 December 2019; pp. 363-370.

64. Elvin, E.; Tepe, K.; Balador, A.; Nwizege, K.S.; Jaimes, L.M. Malicious node detection in vehicular adhoc network using machine learning and deep learning. In Proceedings of the 2018 IEEE Globecom Workshops (GC Wkshps), Abu Dhabi, United Arab Emirates, 9-13 December 2018; pp. 1-6.

65. Guo, X.; Zhang, L.; Liang, W.; Haugen, S. Risk identification of third-party damage on oil and gas pipe-lines through the Bayesian network. J. Loss Prev. Process Ind. 2018, 54, 163-178. [CrossRef]

66. Zhou, Y.; Li, C.; Zhou, C.; Luo, H. Using Bayesian network for safety risk analysis of diaphragm wall deflection based on field data. Reliab. Eng. Syst. Saf. 2018, 180, 152-167. [CrossRef]

67. Mukherjee, S.; Walkery, J.; Rayz, I.; Daily, J. A precedence graph-based approach to detect message injection attacks in J1939 based networks. In Proceedings of the 15th Annual Conference on Privacy, Security and Trust (PST), Calgary, AB, Canada, 28-30 August 2017; pp. 67-76.

68. Su, H.; Zhang, J.; Zio, E.; Yang, N.; Li, X.; Zhang, Z. An integrated systemic method for supply reliability assessment of natural gas pipeline networks. Appl. Energy 2018, 209, 489-501. [CrossRef] 
69. Landucci, G.; Argenti, F.; Cozzani, V.; Reniers, G. Assessment of attack likelihood to support security risk assessment studies for chemical facilities. Process. Saf. Environ. Prot. 2017, 110, 102-114. [CrossRef]

70. Hou, Z.; Zhao, P. Based on Fuzzy Bayesian Network of Oil Wharf Handling Risk Assessment. Math. Probl. Eng. 2016, 2016, 1-10. [CrossRef]

71. Shin, J.; Son, H.; Heo, G. Cyber Security Risk Evaluation of a Nuclear I\&C Using BN and ET. Nucl. Eng. Technol. 2017, 49, 517-524. [CrossRef]

72. Donya, F.; Khakzad, N.; Reniers, G.; Cozzani, V. Security vulnerability assessment of gas pipelines using Discrete-time Bayesian network. Process Saf. Environ. Prot. 2017, 111, 714-725.

73. Liang, H.; Chen, X.; Lai, X. Computer network vulnerability assessment and safety evaluation application based on Bayesian theory. Int. J. Secur. Its Appl. 2016, 10, 359-368.

74. De Galizia, A.; Simon, C.; Weber, P.; Iung, B.; Duval, C.; Serdet, E. Modelling Non-Deterministic Causal Mechanisms involving Resilience in Risk Analysis. IFAC-PapersOnLine 2016, 49, 325-330. [CrossRef]

75. Argenti, F.; Landucci, G.; Reniers, G. Probabilistic vulnerability assessment of chemical plants subjected to external acts of interference. Chem. Eng. Trans. 2016, 48, 691-696. [CrossRef]

76. Chen, Z.; Zhang, Q.; Wu, X.; Yang, J.; Zhang, X. Safety state evaluation and risk management of navigation environment in harbour waters based on Bayesian network. In Proceedings of the 2016 IEEE International Conference on Intelligent Transportation Engineering (ICITE), Singapore, 20-22 August 2016; pp. 80-84.

77. van Staalduinen, M.A.; Khan, F.; Gadag, V. SVAPP methodology: A predictive security vulnerability assessment modeling method. J. Loss Prev. Process. Ind. 2016, 43, 397-413. [CrossRef]

78. Prabhakaran, R.; Krishnaprasad, R.; Nanda, M.; Jayanthi, J. System safety analysis for critical system applications using Bayesian networks. Procedia Comput. Sci. 2016, 93, 782-790. [CrossRef]

79. Chen, X. System vulnerability assessment and critical nodes identification. Expert Syst. Appl. 2016, 65, 212-220. [CrossRef]

80. van Staalduinen, M.; Khan, F. A barrier based methodology to assess site security risk. In Proceedings of the SPE E\&P Health, Safety, Security and Environmental Conference, Denver, CO, USA, 16-18 March 2015. [CrossRef]

81. Tanguy, M.; Napoli, A. A methodology to improve the assessment of vulnerability on the maritime supply chain of energy. In Proceedings of the OCEANS 2015-MTS/IEEE Washington, Washington, DC, USA, 19-22 October 2015; pp. 1-6.

82. Shin, J.; Son, H.; Heo, G. Development of a cyber security risk model using Bayesian networks. Reliab. Eng. Syst. Saf. 2015, 134, 208-217. [CrossRef]

83. Gribaudo, M.; Iacono, M.; Marrone, S. Exploiting Bayesian Networks for the Analysis of Combined Attack Trees. Electron. Notes Theor. Comput. Sci. 2015, 310, 91-111. [CrossRef]

84. Peltola, M.J.; Kekolahti, P. Risk Assessment of Public Safety and Security Mobile Service. In Proceedings of the 10th International Conference on Availability, Reliability and Security, Toulouse, France, 24-27 August 2015; pp. 351-359.

85. Zhou, X.; Zhang, Y. Security Analysis about a Train Control Center Based on a Bayesian Network. ICTE 2015 2015, 2525-2532. [CrossRef]

86. Huo, Y.; Wang, Y.; Lin, W.; Sun, R. Three-layer Bayesian model based spectrum sensing to detect malicious attacks in cognitive radio networks. In Proceedings of the 2015 IEEE International Conference on Communication Workshop (ICCW), London, UK, 8-12 June 2015; pp. 1640-1645.

87. Zhang, K.; Shi, P. Transportation Security Assessment Method for a Mountainous Freeway Using a Bayesian Network. ICTE 2015 2015, 2891-2896. [CrossRef]

88. Bouejla, A.; Chaze, X.; Guarnieri, F.; Napoli, A. A Bayesian network to manage risks of maritime piracy against offshore oil fields. Saf. Sci. 2014, 68, 222-230. [CrossRef]

89. Si, G.; Xu, J.; Yang, J.; Wen, S. An evaluation model for dependability of Internet-scale software on basis of Bayesian Networks and trustworthiness. J. Syst. Softw. 2014, 89, 63-75. [CrossRef]

90. Wang, J.; Zhang, Q.; Ji, W. Construction of monitoring model and algorithm design on passenger security during shipping based on improved Bayesian network. Sci. World J. 2014, 2014, 1-8. [CrossRef] [PubMed]

91. Khan, S.A.; Zafar, N.A.; Ahmad, F.; Islam, S. Extending Petri net to reduce control strategies of railway interlocking system. Appl. Math. Model. 2014, 38, 413-424. [CrossRef]

92. Hang, L.; Shou-Xin, S.; Yu-Hui, Z.; Jia, X.; Qi, Y.; Qian-Hui, H. Probabilistic safety assessment for power transmission and transformation maintenance project based on fault tree analysis and Bayesian network. In Proceedings of the 2014 International Conference on Power System Technology, Chengdu, China, 20-22 October 2014; pp. 1300-1305.

93. Xianfeng, Z. Research on Security Assessment and Maintenance Decision of Trains Based on Bayesian Networks. In Proceedings of the 2014 Sixth International Conference on Measuring Technology and Mechatronics Automation, Zhangjiajie, China, 10-11 January 2014; pp. 534-537.

94. Tian, L.; Zhang, S. Real-Time, Multi-Factors-Coupled Early Warning Model in Water Transportation Safety. In Proceedings of the Fourth International Conference on Transportation Engineering, Chengdu, China, 19-20 October 2013; pp. 1726-1733. [CrossRef]

95. Nzoukou, W.; Wang, L.; Jajodia, S.; Singhal, A. A unified framework for measuring a network's mean time-to-compromise. In Proceedings of the 2013 IEEE 32nd International Symposium on Reliable Distributed Systems, Braga, Portugal, 30 September-3 October 2013; pp. 215-224. 
96. Shin, J.; Son, H.; Heo, G. Cyber Security Risk Analysis Model Composed with Activity-quality and Architecture Model. In Proceedings of the International Conference on Computer, Networks and Communication Engineering (ICCNCE 2013), Beijing, China, 23-24 May 2013. [CrossRef]

97. Dietzel, S.; Petit, J.; Heijenk, G.; Kargl, F. Graph-Based Metrics for Insider Attack Detection in VANET Multihop Data Dissemination Protocols. IEEE Trans. Veh. Technol. 2012, 62, 1505-1518. [CrossRef]

98. Zhao, J.; Zheng, W. Study of fault diagnosis method based on fuzzy Bayesian network and application in CTCS-3 train control system. In Proceedings of the 2013 IEEE International Conference on Intelligent Rail Transportation, Beijing, China, 30 August-1 September 2013; pp. 249-254.

99. Hird, J.; Koelle, R.; Kolev, D. Towards mathematical modelling in security risk management in system engineering. In Proceedings of the 2013 Integrated Communications, Navigation and Surveillance Conference (ICNS), Herndon, VA, USA, 22-25 April 2013; pp. 1-13.

100. Eom, H.-S.; Park, G.-Y.; Jang, S.-C.; Son, H.S.; Kang, H.G. V\&V-based remaining fault estimation model for safety-critical software of a nuclear power plant. Ann. Nucl. Energy 2012, 51, 38-49. [CrossRef]

101. Chaze, X.; Bouejla, A.; Napoli, A.; Guarnieri, F. Integration of a bayesian network for response planning in a maritime piracy risk management system. In Proceedings of the 2012 7th International Conference on System of Systems Engineering (SoSE), Genova, Italy, 16-19 July 2012; pp. 137-142.

102. Ming-Zhong, M. Network Security Analysis Based on Graph Theory Model with Neutral Network. In Future Communication, Computing, Control and Management; Springer: Berlin/Heidelberg, Germany, 2012; pp. 551-557.

103. Wang, S.; Hong, L.; Chen, X. Vulnerability analysis of interdependent infrastructure systems: A methodological framework. Phys. A Stat. Mech. Appl. 2012, 391, 3323-3335. [CrossRef]

104. Lu, S.; Wu, D.; Lu, S.; Zhang, H. A Bayesian network model for the Asian Games fire risk assessment. In Proceedings of the International Conference on Information Systems for Crisis Response and Management (ISCRAM), Harbin, China, 19-22 October 2011; pp. 350-355.

105. Cavalheiro, A.C.; Fo, D.J.S.; Andrade, A.; Cardoso, J.R.; Horikawa, O.; Bock, E.; Fonseca, J. Specification of Supervisory Control Systems for Ventricular Assist Devices. Artif. Organs 2011, 35, 465-470. [CrossRef] [PubMed]

106. Chockalingam, S.; Pieters, W.; Teixeira, A.; van Gelder, P. Bayesian network models in cyber security: A systematic review. In Secure IT Systems; Springer: Cham, Switzerland, 2017; pp. 105-122.

107. Contreras-Reyes, J.E.; Quintero, F.O.L.; Wiff, R. Bayesian modeling of individual growth variability using back-calculation: Application to pink cusk-eel (Genypterus blacodes) off Chile. Ecol. Model. 2018, 385, 145-153. [CrossRef] 